Historic, archived document

Do not assume content reflects current scientific knowledge, policies, or practices. 

7642
$o p .2$

Forest Service Research Paper INT-18, 1965

\section{INFLUENCE OF MOISTURE ON}

\section{EFFECTIVENESS OF FIRE RETARDANTS}

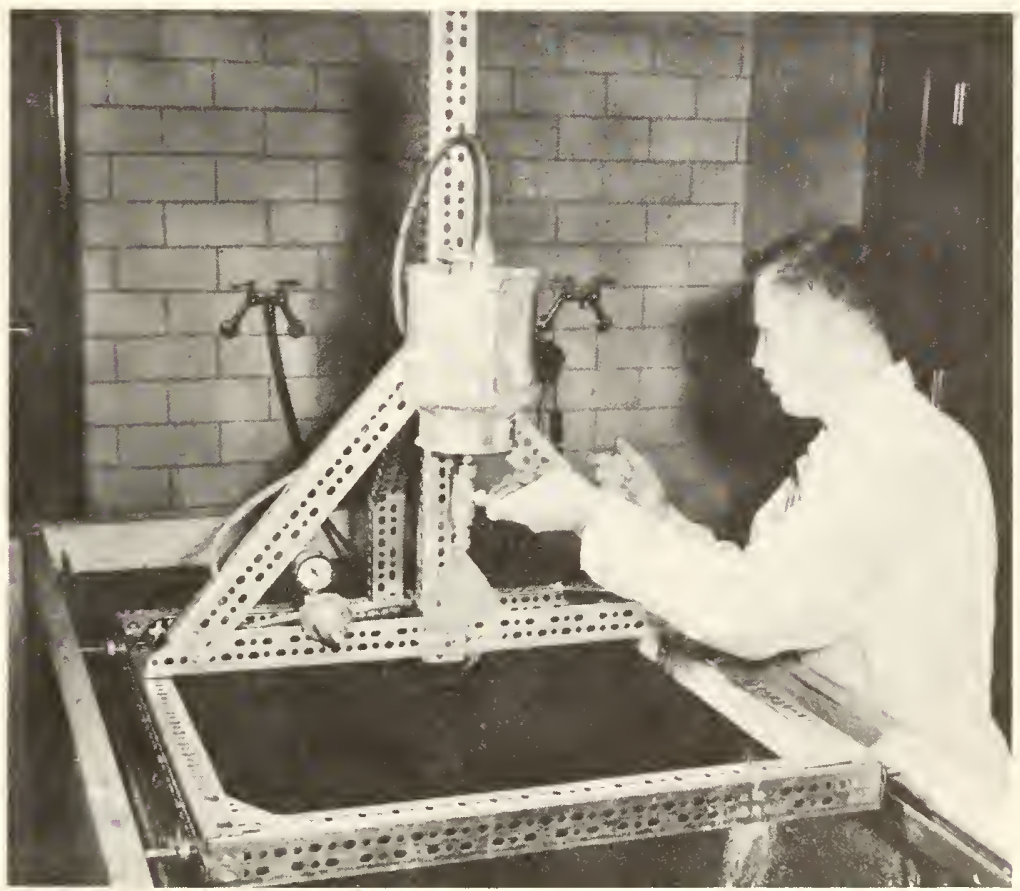

by

Richard C. Rothermel and Charles E. Hardy Northern Forest Fire Laboratory 

U.S. Forest Service

Research Paper INT-18

1965

INFLUENCE OF MOISTURE ON EFFECTIVENESS OF

FIRE RETARDANTS

by

Richard C. Rothermel and Charles E. Hardy

INTERMOUNTAIN FOREST AND RANGE EXPERIMENT STATION

Forest Service

U.S. Department of Agriculture

Ogden, Utah

Joseph F. Pechanec, Director 


\section{THE AUTHORS}

RICHARD C. ROTHERMEL received his bachelor's degree in aeronautical engineering from the University of Washington in 1953. After serving as project officer at the Air Force Special Weapons Center in Albuquerque, N. Mex., he worked in the armament group at Douglas Aircraft Company, Long Beach, Calif. After 4 years' work on General Electric's Nuclear Powered Aircraft Engine project, Dick joined the staff of the Northern Forest Fire Laboratory in 1961. He is now working in the Fire Physics Project.

CHARLES E. HARDY, a native of southern California, received his B.S.F. degree at University of Montana and the M.F. degree at University of Michigan. He spent several years in National Forest administration on ranger districts and on fire control and timber management projects. Since entering forest fire research in 1951 he has specialized in fire control management problems. 


\section{CONTENTS}

$\underline{\text { Page }}$

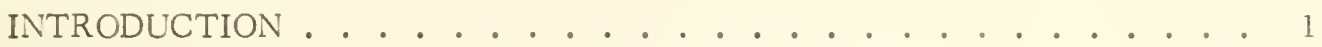

The Problem . . . . . . . . . . . . . . . . 1

Objectives . . . . . . . . . . . . . . . . 2

INITIAL CONSIDERATIONS . . . . . . . . . . . . . 2

Chemicals................... . . 2

Fuel ..................... 3

Environment . . . . . . . . . . . . . . 4

CHEMICAL APPLICATION . . . . . . . . . . . . . . 4

Essential Features . . . . . . . . . . . . 4 4

Equipment. . . . . . . . . . . . . . . 5

Calibration .. . . . . . . . . . . . 6

Retardant Application. . . . . . . . . . . . . . 7

Operation of Retardant Application Equipment . . . . . . . . 8

TESTING PROCEDURE . . . . . . . . . . . . . . . . 9

Drying Test . . . . . . . . . . . . . . . . 9

Burning Test . . . . . . . . . . . . . 10

RESULTS . . . . . . . . . . . . . . . . 12

Drying Test .................. . . . 12

Burning Test . . . . . . . . . . . . . 22

CONCLUSIONS . . . . . . . . . . . . . . . . . . 25

APPENDIX. . . . . . . . . . . . . . . . . 27 



\title{
INFLUENCE OF MOISTURE ON EFFECTIVENESS OF FIRE RETARDANTS
}

\author{
Richard C. Rothermel and Charles E. Hardy
}

\section{INTRODUCTION}

\section{The Problem}

Application of fire-retardant chemicals is fast becoming an integral part of control procedures on forest, range, and brushland fires. Each year new fire-retardant chemicals or combinations of chemicals are introduced, and existing retardants are improved. Fire-control personnel urgently need more information about the effectiveness of present. types of retardants as influenced by the environment.

A complete series of tests for each new or modified product is not economically feasible. Instead, procedures are being developed to classify fire-retardant chemicals so that a minimum number of tests will make it possible to list each one within a group having similar characteristics.

All research reported in this publication was performed at the Northern Forest Fire Laboratory, Missoula, Montana. It explored the relation between effectiveness of each fire retardant and fuel moisture content as influenced by such environmental conditions as wind velocity, humidity, and temperature.

Fire retardants may be classified generally as short-term or long-term retardants. Short-term retardants rely entirely upon the water they contain to prevent combustion. Longterm retardants contain, in addition to water, a chemical that effectively prevents flaming combustion even after the water has evaporated.

Much conjecture surrounds the question of comparative evaporation rates among the various retardant materials. If differences do exist, the slowest drying material is the most desirable one to use in fire control. Determination of evaporation rates in this study is important not only as a prerequisite to the burning tests, but also as an aid in selecting the most effective retardant thickening or water-holding material.

Results from earlier research at the Northern Forest Fire Laboratory ${ }^{\mathcal{1}}$ indicated that long-term retardants--those containing fire-retarding salts--are markedly more effective than short-term retardants. The present study was more concerned with how wind and relative humidity affect the rapidity of moisture loss from retardant-treated fuels than on how moisture affects the burning characteristics of retardant-treated fuels.

Both experience and previous research show the superiority of long-term over short-term retardants. However, the short-term retardants continue to be used because they cost less and some of them are easier to mix and use. Results of this study should help the fire-control

${ }^{1}$ Hardy, C. E., R. C. Rothermel, and J. B. Davis. Evaluation of forest fire retardants-a test of chemicals on laboratory fires. U.S. Forest Serv., Intermountain Forest and Range Expt. Sta. Res. Paper 64, 33 pp., illus. 1962. 
officer determine what environmental conditions justify use of short-term retardants, and what conditions force him to apply the more costly, but more effective, long-term type.

\section{Objectives}

The major objective of this study was to learn the extent to which environment affects the ability of retardants to slow or stop an advancing fire (1) when the degree of retardant dryness changes, (2) when different amounts of retardant material are applied to the fuel bed, and (3) when ammonium salts should be included in the retardant formulation.

The experiments were of two sorts:

Drying test.--Determination of drying rates of several fire-retardant formulations. fire situation.

The study was designed to yield information that could ultimately be used in developing operational guidelines. These guidelines would assist fire-control officers in choosing the proper type of retardant, and in determining how much to use, according to the fuel and environmental situation at hand.

\section{INITIAL CONSIDERATIONS}

Three major elements received primary consideration in developing the study plan:

1. Retardant chemicals--selection of types, amounts, and methods of application .

2. The composition of fuel beds upon which each retardant would be applied.

3. Environmental regimes within which the drying and burning tests would be conducted.

\section{Chemicals}

Retardants now being used against wildfire consist of water thickened by either a natural organic gum, a synthetic organic gum, or a swelling clay. Use of the thickened material assures that a large percentage of the original volume will reach the ground instead of breaking up into a mist and drifting off, that it will cling to all parts of the fuel surface, that it will build up a thick layer of moisture that will be a barrier between the fuel and the flame, and that this moisture barrier will evaporate more slowly than would a thin film of plain water.

The ability of the thickened material to retard fire is increased substantially by adding a salt--usually an ammonium salt such as ammonium sulfate or diammonium phosphate. The ammonium salt alters the combustion characteristics of the fuel, causing it to char rather than flame; this reduces heat transfer which, in turn, inhibits spread of the fire. The inhibiting action persists even though the retardant's moisture has evaporated from the surface of the fuel.

Representative retardants selected for this study are classified by effective life and thickening agents (table 1). 
Table 1.--Classification of retardants by effective life and thickening agents

\begin{tabular}{lcccc}
\hline \multirow{2}{*}{ Retardant $^{1}$} & $:$ & \multicolumn{2}{c}{ Effective life } & \multicolumn{2}{c}{ Thickening agent } \\
\cline { 2 - 4 } Gelgard & Short-term & Long-term & Clay & Gum \\
Algin-gel & $\mathrm{X}$ & & $\mathrm{X}$ \\
Bentonite & $\mathrm{X}$ & $\mathrm{X}$ & $\mathrm{X}$ \\
Phos-Chek 202 & $\mathrm{X}$ & & $\mathrm{X}$ \\
Fire-Trol & & $\mathrm{X}$ & $\mathrm{X}$ & \\
\hline
\end{tabular}

NOTE: Table 7, p. 28, shows composition, mixing quantities, and method of mixing.

${ }^{1}$ Mention of trade or brand names is solely for convenience in identification. Such mention does not imply endorsement by the U.S. Forest Service of the products mentioned, nor does it imply nonendorsement of unnamed products.

All five retardants and water were used in the drying test. Water, however, penetrated through the fuel instead of adhering to it, and formed puddles on the bottom of the drying pans. This caused spurious drying rates; hence we eliminated water from further consideration in the present study.

We used only one short-term and one long-term retardant in the burning test on the assumptions that:

1. Short-term retardants have similar fire-inhibiting characteristics.

2. Long-term retardants, as now manufactured, have similar fire-inhibiting characteristics.

3. The fire-inhibiting characteristics of long-term retardants as a group are significantly different from those of short-term retardants.

\section{Fuel}

We used ponderosa pine needles for fuel bed material in all tests because of their natural organic composition and also because pine-needle beds can be reproduced with reasonable accuracy; ${ }^{2}$ also, pine needles are readily available. Earlier research analyzed the burning of untreated ponderosa pine fuel beds under a wide range of fuel and air moisture content and environmental conditions; the results were the basis for comparison of the burning phenomena of treated and untreated fuels. ${ }^{3}$

Needles from the current year's cast were cleaned, mixed, and stored in bins. At least 2 weeks prior to use the needles were place in 10-pound-capacity wire baskets on open shelves in the fuel preparation room, where the ambient environmental conditions caused the moisture

${ }^{2}$ Schuette, Robert D. Preparing reproducible pine needle fuel beds. U.S. Forest Serv. Research Note INT-36, 7 pp., illus. 1965.

${ }^{3}$ Rothermel, R. C., and Hal E. Anderson. Fire spread characteristics determined in the laboratory. (In preparation.) 
content of the needles to lie between 6.0 and 7.0 percent of their ovendry weight. Further conditioning of the needles to bring them into equilibrium moisture content with the environment in which they would be burned was not necessary because the entire fuel bed was to be coated with a moisture-laden retardant.

Pine needles were distributed over each fuel bed to a loading density of 0.5 pound per square foot. Thus, each 18 - by 24 -inch drying pan contained 1.5 pounds of needles, and each 18- by 96 -inch burning tray contained 6 pounds. To build reproducible 8 -foot-long fuel beds with uniform compactness, we followed Schuette's ${ }^{4}$ published instructions. A similar procedure was followed in preparing the 2-foot-long drying pans and the 3-foot-long "igniter" fuel beds.

\section{Environment}

All testing reported here was performed in the laboratory's large wind tunnel. Test objectives specified three variations of environment for both drying and burning tests; to achieve these, we combined two relative humidities and two wind velocities at a temperature of $90^{\circ} \mathrm{F}$. (table 2).

Table 2.--Environmental conditions

\begin{tabular}{|c|c|c|c|c|c|c|c|c|}
\hline \multirow[t]{2}{*}{ Condition } & \multirow{2}{*}{$\begin{array}{l}: \\
: \text { Temperature } \\
:\end{array}$} & \multirow{2}{*}{$\begin{array}{l}: \\
: \\
:\end{array}$} & \multirow{2}{*}{$\begin{array}{l}\text { Relative } \\
\text { humidity }\end{array}$} & \multicolumn{3}{|c|}{ Wind velocity } & & \multirow{2}{*}{$\begin{array}{l}\text { :National spread } \\
: \quad \text { index } \\
: \text { equivalent } \\
\end{array}$} \\
\hline & & & & : & 1 foot & $: 20 \mathrm{feet}^{I}$ & & \\
\hline & Degrees F. & & Percent & & --- & M.p.h. - - - & -- & \\
\hline I & 90 & & 50 & & 2 & 6 & & 36 \\
\hline II & 90 & & 20 & & 2 & 6 & & 40 \\
\hline III & 90 & & 20 & & 5 & 15 & & 68 \\
\hline Tolerance & \pm 1.0 & & \pm 1.0 & & \pm 0.25 & & & \\
\hline
\end{tabular}

${ }^{I}$ A 3-to-1 difference in windspeed between the fuel surface and an anemometer at 20 feet is assumed. This value may change drastically according to the boundary layer created by the surface vegetation.

${ }^{2}$ National Fire-Danger Rating System, Fine Fuel Moisture--Cured Herbaceous Stage, U.S. Dept. Agr. Forest Serv. Form 5100-24 (2/64).

\section{CHEMICAL APPLICATION}

\section{Essential Features}

Immediately before impact with the fuel, physical characteristics vary greatly among retardant formulations--even within a specific drop of a single retardant. Viscosity may be much less while a retardant is falling through the air than when it is at rest; this change in viscosity influences droplet size, both in average diameter and in range of diameters; in turn, the droplet's velocity is affected. All these factors, along with the total amount applied, affect the retardant's penetration into the fuel bed. The following six essential features were incorporated into the application technique to produce a retardant drop pattern that would most closely simulate actual drop conditions:

\footnotetext{
${ }^{4}$ Schuette, op. cit., p. 3.
} 
1. Application of the total specified amount of retardant on the upper surface of the completed fuel bed. (Preliminary burning tests had shown this to be feasible.)

2. Use of an application device that would not aerate the retardant. This was done by pressurizing the supply tank just enough to force the liquid out the bottom into a manageable spray pattern.

3. Selection of a nozzle and pressure combination that effectively prevents formation of fine mist and large globs.

4. Use of a flat or single-plane nozzle to obtain a uniform lateral spray pattern over the full width of the fuel bed.

5. Reduction of particle velocity to as near terminal rate as possible without sacrificing requirements of droplet size, spray pattern, or flow rate.

6. Increasing application time to permit better control of application amount by reducing flow rate as much as practicable. The rate achieved was between 1.7 and 2.0 gallons per minute.

\section{Equipment}

Application equipment consisted of a 12 -foot-long spray chamber with tracks along each side to support the carriage containing the pressurized applicator (fig. 1).

Figure 1.--Application equipment.

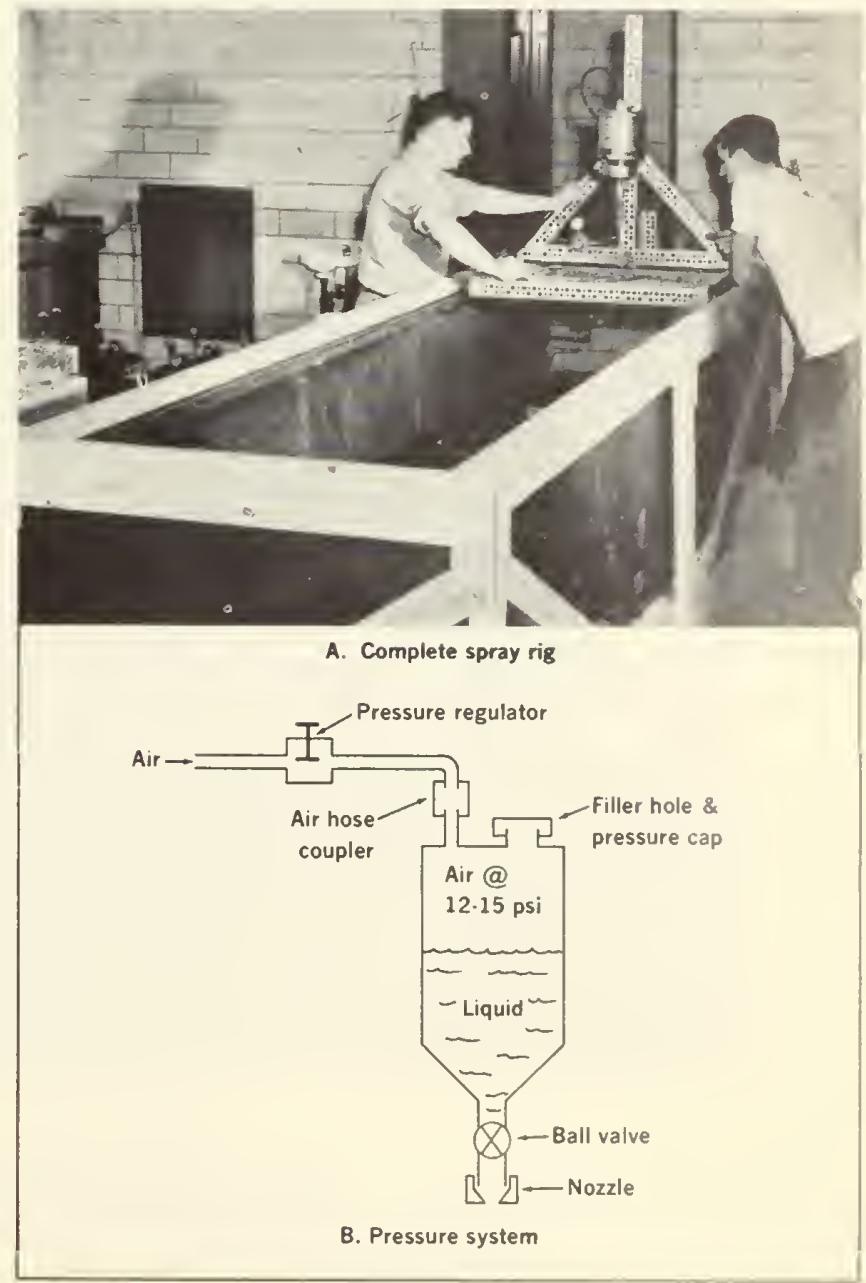


Each retardant was calibrated to determine its total flow rate, lateral pattern uniformity, and usable flow rate.

\section{Total Flow Rate}

Flow rates were measured at tank pressures between 3 and 21 p.s.i., and at five orifice sizes of 5/64 to $11 / 64$ inch, by timing the discharge of 1 gallon of each retardant and converting the information to gallons per minute.

\section{Lateral Pattern Uniformity}

We achieved optimum uniformity of retardant amount at all points across the 18-inch tray width by: (1) spraying each retardant for 10 seconds into plastic ice cube trays arranged across the spray chamber floor to intercept the spray, using varied nozzle heights and the array of pressures and orifices described above in Total Flow Rate (also see fig. 2); (2) weighing each tray; and (3) after examining results, choosing the nozzle type, nozzle height, and tank pressure that produced the best pattern for each retardant across the usable 18-inch span.

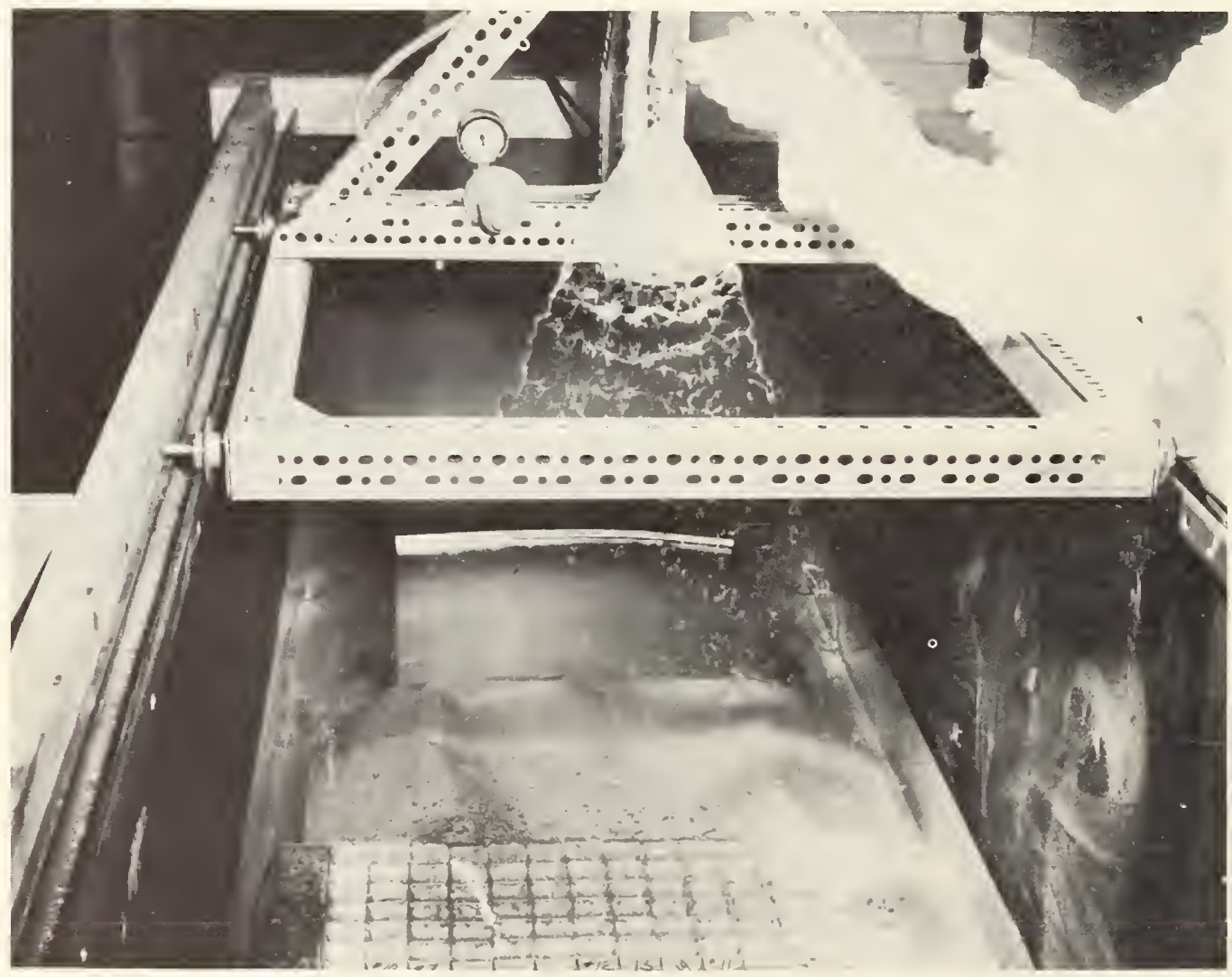

Figure 2.--Pattern calibration. 
While the above procedure laterally oversprayed and lost considerable volume to each side of the fuel bed, it produced a uniform pattern over the 18-inch fuel bed width. The actual amount of material falling into the fuel bed per second was determined by spraying directly into 18-inch-wide pans for a given time period, then weighing the pans and computing the rate.

Table 3 shows the resultant usable flow rates.

Table 3. - -Retardant calibration and application data

(based on rate of 1 gallon per 100 square feet)

\begin{tabular}{|c|c|c|c|c|c|c|c|c|c|}
\hline \multirow{2}{*}{ Retardant } & \multirow{2}{*}{$\begin{array}{l}\text { :Calibration: } \\
\text { : Measured } \\
\text { : density }^{1}:\end{array}$} & \multirow{2}{*}{$\begin{array}{l}\text { Flow } \\
\text { rate }\end{array}$} & \multirow{2}{*}{$\begin{array}{l}\text { Viscos- } \\
: \text { ity }^{3} \\
\end{array}$} & \multirow{2}{*}{$\begin{array}{l}: \\
: \text { Time } \\
\\
\end{array}$} & \multicolumn{5}{|c|}{ Application amount ${ }^{5}$} \\
\hline & & & & & \multicolumn{2}{|c|}{ Chemical } & \multicolumn{2}{|c|}{ Water } & \multirow{2}{*}{$\begin{array}{c}\text { Total } \\
\text { Grams }\end{array}$} \\
\hline & Lb./gal. & G.p.m. & C.p.s. & Sec. & Grams & Percent & Grams & Percent & \\
\hline & & & & \multicolumn{6}{|c|}{ Drying Pans } \\
\hline Gelgard & 8.36 & 1.82 & - & 2.4 & 1 & 1 & 114 & 99 & 114 \\
\hline Algin-gel & 8.33 & 1.92 & 1,360 & 2.5 & 1 & 1 & 113 & 99 & 113 \\
\hline Bentonite & 8.76 & 2.00 & 5,090 & 1.9 & 10 & 8 & 109 & 92 & 119 \\
\hline Phos-Check 202 & 8.83 & 1.85 & 2,610 & 1.9 & 14 & 11 & 106 & 89 & 120 \\
\hline \multirow[t]{3}{*}{ Fire-Trol } & 9.49 & 2.00 & 2,637 & 2.5 & 32 & 25 & 97 & 75 & 129 \\
\hline & & & & \multicolumn{6}{|c|}{ Burning Trays } \\
\hline & & & & Sec. & Lbs. & Percent & Lbs. & Percent & Lbs. \\
\hline Short-term & & & 3,505 & 7.8 & 0.09 & 8 & 0.96 & 92 & 1.05 \\
\hline Long-term & & & 2,780 & 10.0 & .29 & 25 & .85 & 75 & 1.14 \\
\hline
\end{tabular}

\footnotetext{
${ }^{1}$ Residual bubbles may have caused minor errors, even though at least 18 hours elapsed between mixing and measuring.

${ }^{2}$ Nozzle tip diameter: 9/64 inch; tank pressure: Phos-Check $202-15$ p.s.i.; all others - 12 p.s.i.

${ }^{3}$ See table 7, p. 28.

${ }^{4}$ Nozzle height above fuel bed: Phos-Check $202-110 \mathrm{~cm}$; all others $-100 \mathrm{~cm}$.

${ }^{5}$ By volume: $0.01 \mathrm{gal} . / \mathrm{sq}$.ft. for all retardants.
}

$\underline{\text { Retardant Application }}$

\section{Selection of Amounts}

Retardant dropped from an air tanker does not form a uniform lateral layer on the ground. The amount may vary from less than 0.5 gallon per hundred square feet $(0.5$ gal. $/ 100$ sq. ft.) to more than 5.0 gal. $/ 100 \mathrm{sq}$. ft. Seldom does a continuous strip of air-dropped retardant contain more than 3.0 gal./100 sq.ft. From this range of field-attainable amounts we used the quantities of 1,2, and $3 \mathrm{gal} . / 100 \mathrm{sq}$. ft. for the series of drying and burning tests. Preliminary burning tests verified that these amounts would produce a satisfactory range of results.

\section{Penetration}

Application of all the retardant onto the upper surface of the 3-inch-deep fuel bed created a situation similar to what occurs in field application--an unequal vertical distribution of the 
Figure 4.-- Weighing drying pan.

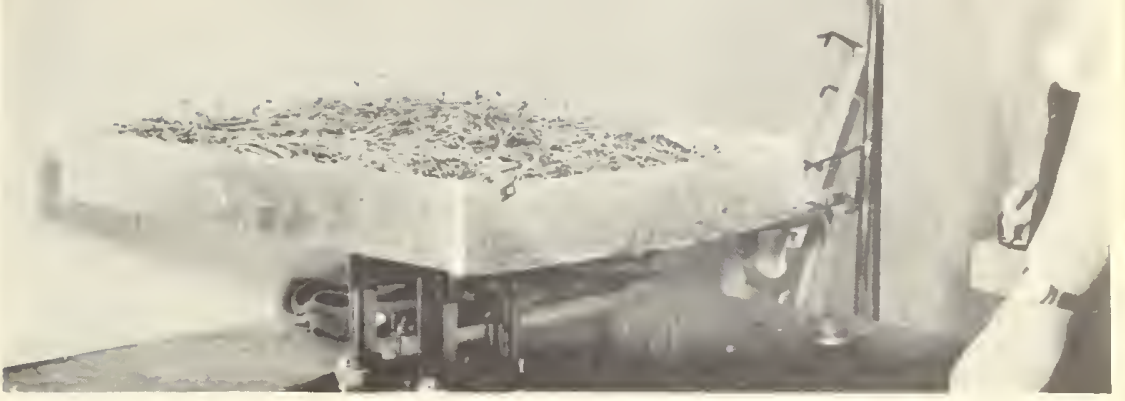

TESTING PROCEDURE

\section{Drying Test}

To determine the drying rates of the various retardants, each sample was weighed at 15minute intervals until it was essentially dry. The results were then plotted as drying curves.

Nine runs were made, each with 18 treated samples:

Variable

Chemicals, including water

Environments

Application amounts

Replications

Total samples
Number of treatments

$\begin{array}{r}6 \\ \times 3 \\ \times 3 \\ \times 3 \\ \hline 162\end{array}$

Before running any tests, we positioned a 20-compartment rack across the wind tunnel test section to expose the treated pans to the environmentally conditioned airflow. The treatment sequence and order of placement in the rack were determined by random number selection before the test series began.

Figure 5.--Weighing burning tray.

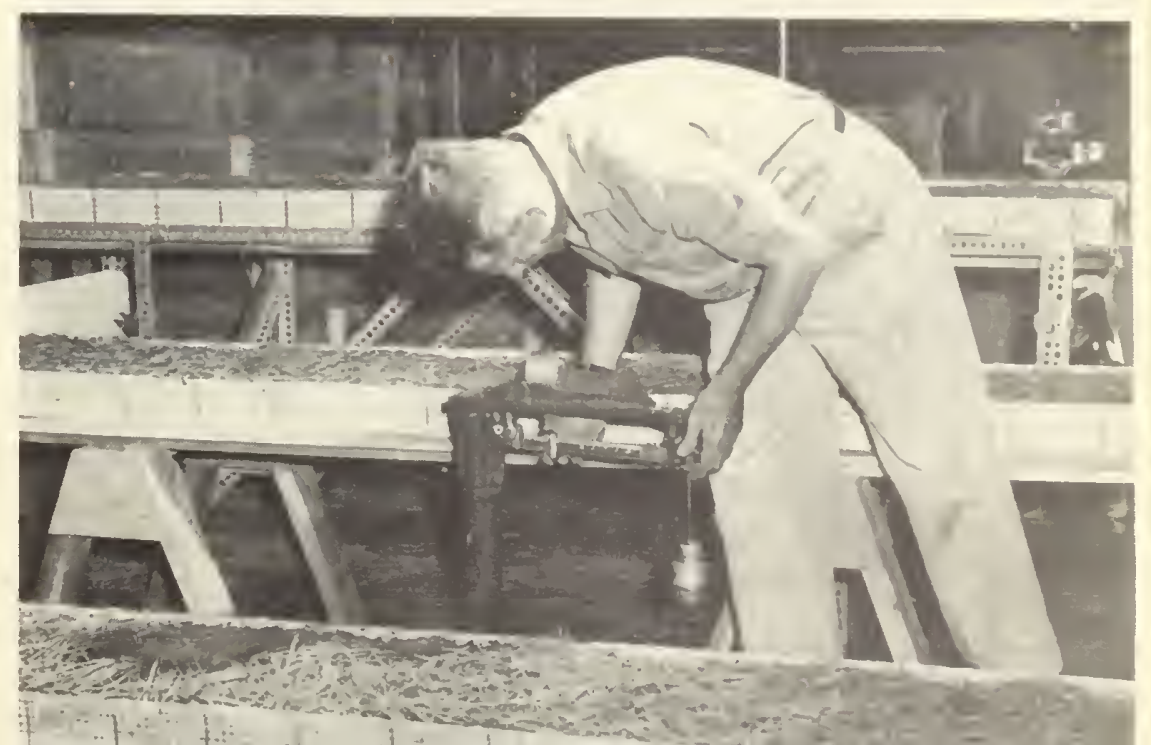


During a run (1 day's operation) we applied a specified amount of each of the six retardants $(1,2$, or 3 gal./100 sq.ft.) to each of three 3 - by 18 - by 24 -inch pans. The entire group of 18 pans was then subjected to one of the three environmental conditions (I, II, or III) described in tables 2 and 3 .

The operator reweighed each pan to the nearest gram on a direct-reading balance after he brought it into the wind tunnel and before placing it in its assigned cell. Weighing continued at 15-minute intervals until the loss in moisture showed a difference of 2 grams or less between any three readings. After each weighing the pans were rotated in sequential order from cell to cell to reduce any effect of possible unequal airflow through the wind tunnel's cross section (fig. 6).

\section{Burning Test}

\section{Burning Plan}

The burning plan held the total number of test fires to a minimum by restricting the number of considerations. The considerations to be covered were two retardant types, three environmental conditions, three drying times, three application amounts, and three replications of each test. Complete coverage of all these would have required 162 fires, plus reruns in the event of instrument failure. Such complete coverage was beyond the scope of our time, budget, and fuel supply; however, the number of tests finally chosen covered the most pertinent data and answered our questions satisfactorily.

The total number of fires actually burmed was held to 73 by reducing the number of drying conditions from three to two and by adjusting the application amounts as dictated by the test conditions. The short-term retardants were tested when they were 33-and 67-percent dry; the long-term retardants, when they were 67 - and 95-percent dry. Since previous testing ${ }^{6}$ had shown that short-term retardants were ineffective after severe drying, there seemed to be no need to test short-term retardants when they were 95-percent dry. The same report clearly showed long-term retardants to be superior to short-term retardants under any given condition, and thus eliminated need for extensive comparative testing now.

\section{${ }^{6}$ Hardy et al., op. cit., p. 1 .}

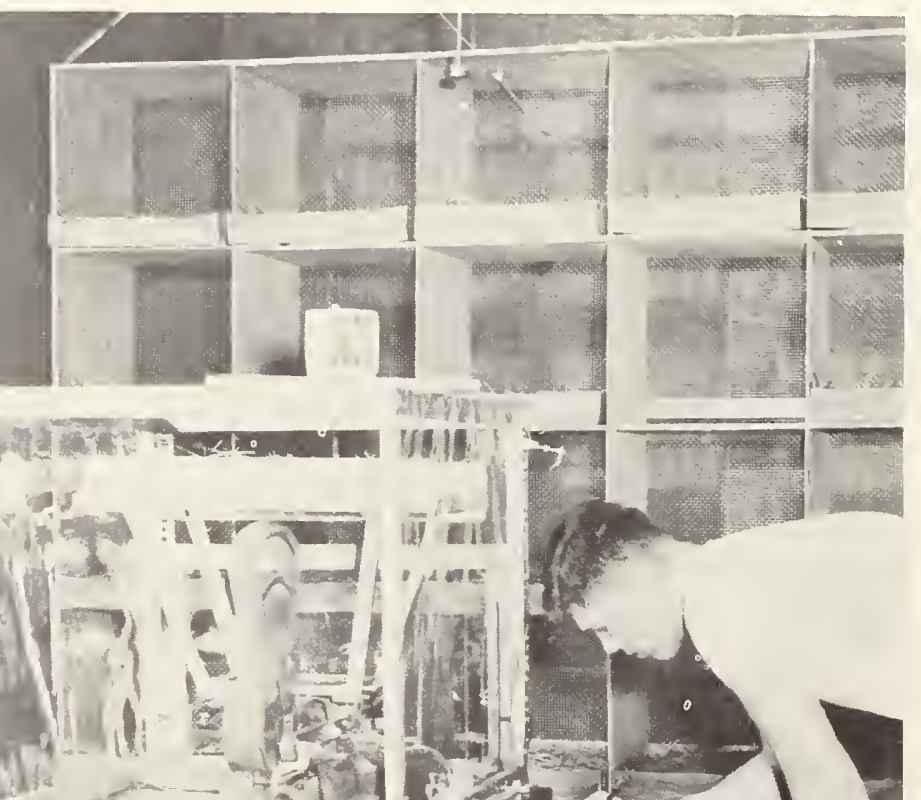

Figure 6.--Drying test equipment in wind tunnel. Rack in background has screen and baffles on upwind side to establish uniform airflow over the pans. 
In this study, fires on which the retardants were judged to be effective continued to burn deep within the fuel bed where there was little or no retardant. These fires could have been stopped easily by a heavier application of retardant or by deeper penetration, or by a break in fuel continuity such as is found in wildland fuels.

The amount of retardant to be applied was determined by using first the median amount at each new condition, and then adjusting the next amount of application according to the success or failure of the first amount. The amounts applied thus varied from 1 to 3 gallons per $100 \mathrm{sq}$. $\mathrm{ft}$. If the retardant was judged to be effective, even with the minimum application, the environmental conditions were increased to a higher Spread Index for the next series of tests. If judged ineffective, the quantity of retardant applied was increased.

\section{Positioning of Tray}

Immediately after the 3 - by 18 - by 96 -inch burning tray had been treated, the operator lifted it into the large wind tunnel and placed it on the strain gage weighing system attached to the fixed support frame (fig. 7). An untreated 3 - by 18 - by 36 -inch fuel bed (igniter tray) placed upwind from the longer, treated bed afforded the fire a chance to approach a steady rate of advance before it came in contact with the retardant-treated fuel--a situation comparable to what might occur in nature. End and side ground plane aprons designed to produce uniform airflow over the needle surface were placed on all sides of the treated and igniter trays. The final preparation included placing the alcohol ignition trough at the upwind end of the igniter tray.

\section{Drying}

The fuel bed was ready to be burned as soon as the designated amount of retardantassociated moisture had evaporated. The evaporation was monitored on the same weighing system used to measure rate of fuel consumption during the fire.

Ignition

Just before test time, an observer poured $15 \mathrm{cc}$. of alcohol into the ignition trough. A remotely controlled electric spark ignited the alcohol, which in turn set afire the igniter tray of untreated needles. The fire in the untreated fuel bed established a strong flame front, which burned into the retardant-treated fuel bed.

Figure 7.---Instrumented support frame in wind tunnel. Note the side and front ground planes in place.

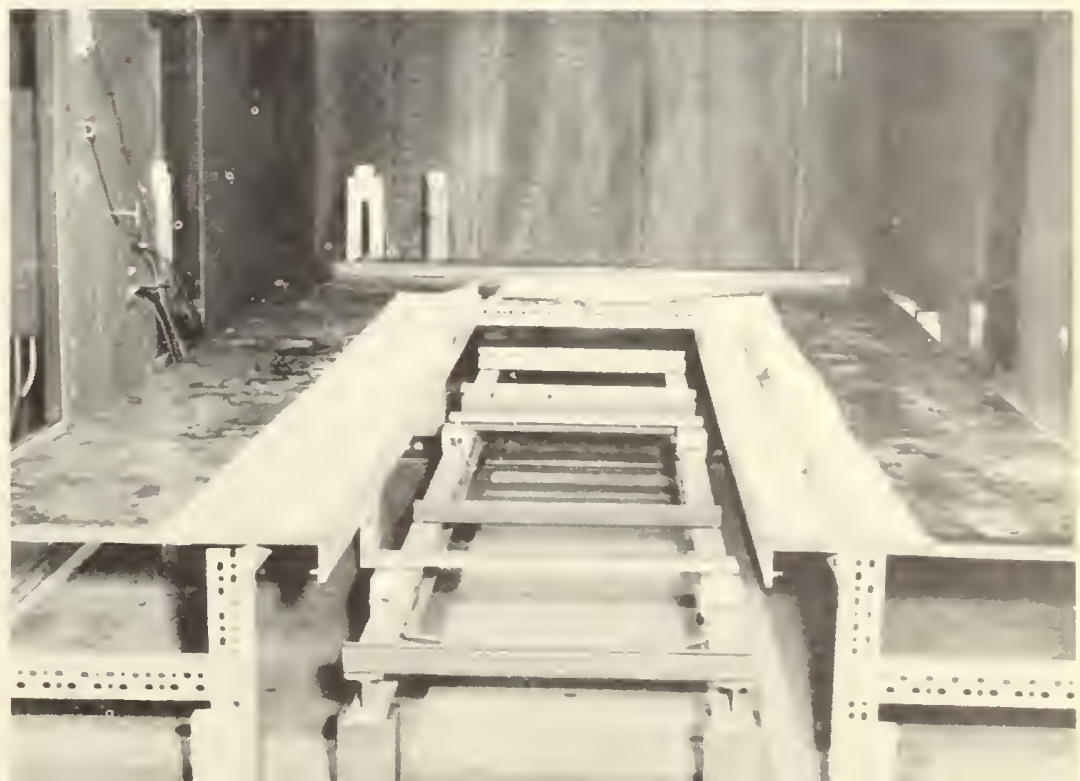


Records began when needles on the treated fuel bed first caught fire.

Rate of spread.--A marker board lay alongside the untreated fuel bed. An observer with a stopwatch recorded the length of time required for the fire front to travel each 6-inch increment of fuel bed. He also noted any unusual or erratic behavior.

Weight loss.--The loss of weight as the flame front advanced was measured by a system of strain gages used as the sensing element; it transmitted the information onto a strip chart recorder. The record was continued after the flames reached the end of the fuel bed until no more appreciable loss was encountered.

Radiation.--A radiometer mounted 8 feet above the fuel bed measured and transmitted to a strip chart recorder the radiant energy released between the 5- and 7 -foot marks of the burning fuel bed.

\section{RESULTS}

\section{$\underline{\text { Drying Test }}$}

Results of the drying test are shown in figures $8 \mathrm{a}, 8 \mathrm{~b}$, and $8 \mathrm{c}$. These uncorrected data clearly show that the retardants dry according to the environmental conditions as well as the initial amount of retardant applied. Contrary to popular belief, all retardants dry at practically the same rate. Retardants applied in heavier application amounts than the mean stayed high in the grouping; conversely, those that were applied lighter than the mean stayed low. Any real difference in drying rate would be shown by crossing lines and definite trends away from the mean; to be significant, such divergences would have to exist in all nine conditions tested. No such trends are apparent.

The data shown in all three parts of figure 8, when plotted on semilog paper, produce straight lines until the retardant is almost dry. The deviation at the dry end of the curve is attributed to the depletion of surface water and the slower release of water from within the fuel itself. An equation for the straight portion of the line is:

$$
M=M_{O} e^{-r t}
$$

where: $\quad M=$ moisture at any time (grams)

$$
\begin{aligned}
M_{O} & =\text { initial amount of moisture (grams) } \\
r & =\text { drying rate constant } \\
t & =\text { time (minutes) } \\
e & =\text { the base of natural logarithms }
\end{aligned}
$$

Equation (1) is the integrated form of the classical differential equation: ${ }^{7}$

$$
\frac{\mathrm{dM}}{\mathrm{dt}}=\mathrm{rM}
$$

Equation (2) shows that the change of $\mathrm{M}$ with time depends upon a constant $\mathrm{r}$ and the amount $M$ that is present at that time.

7 The form of equations (1) and (2) is used to describe the discharge of a capacitor, the growth of bacteria, or, as Sir Isaac Newton showed, the cooling of a cannonball. 


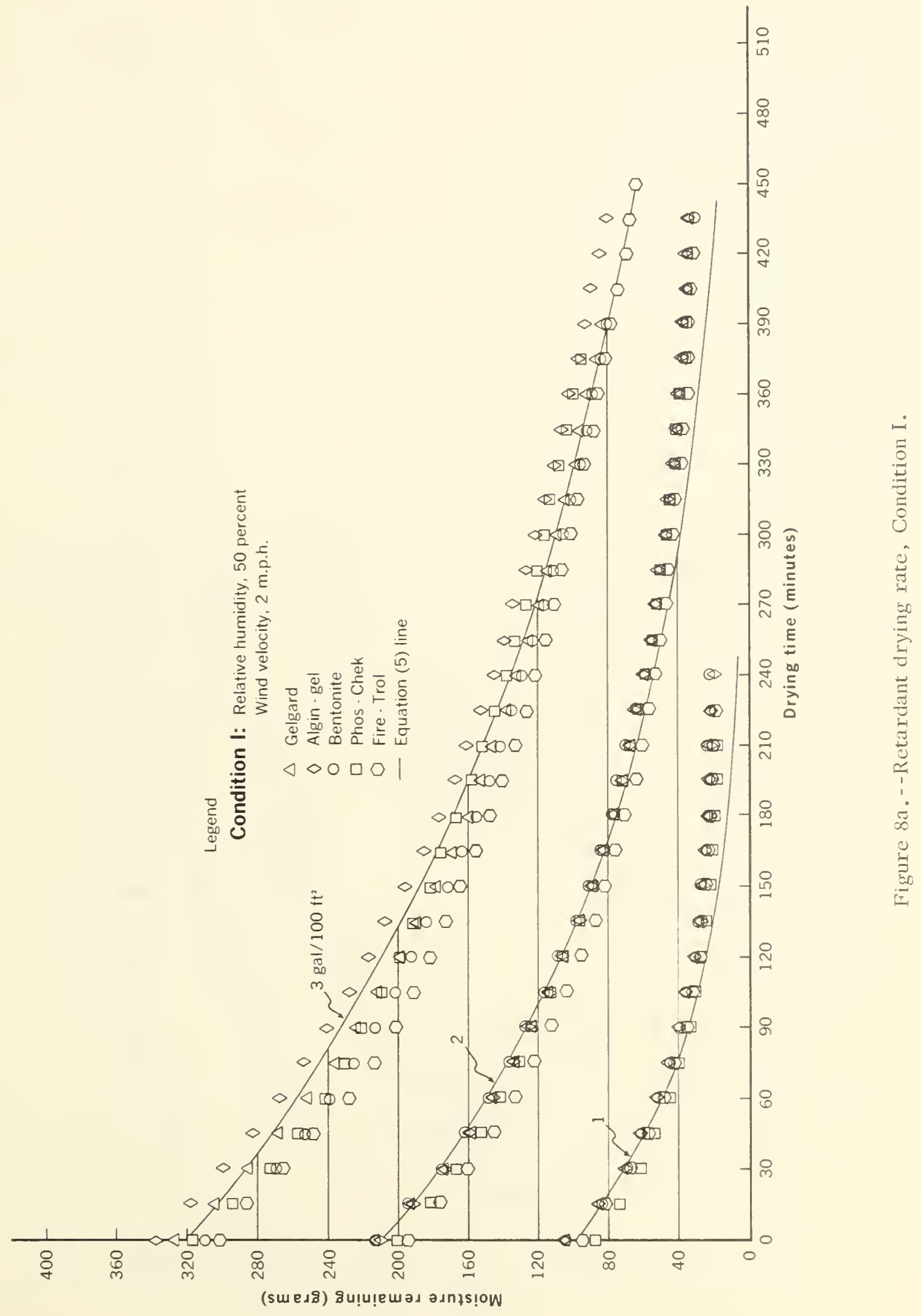




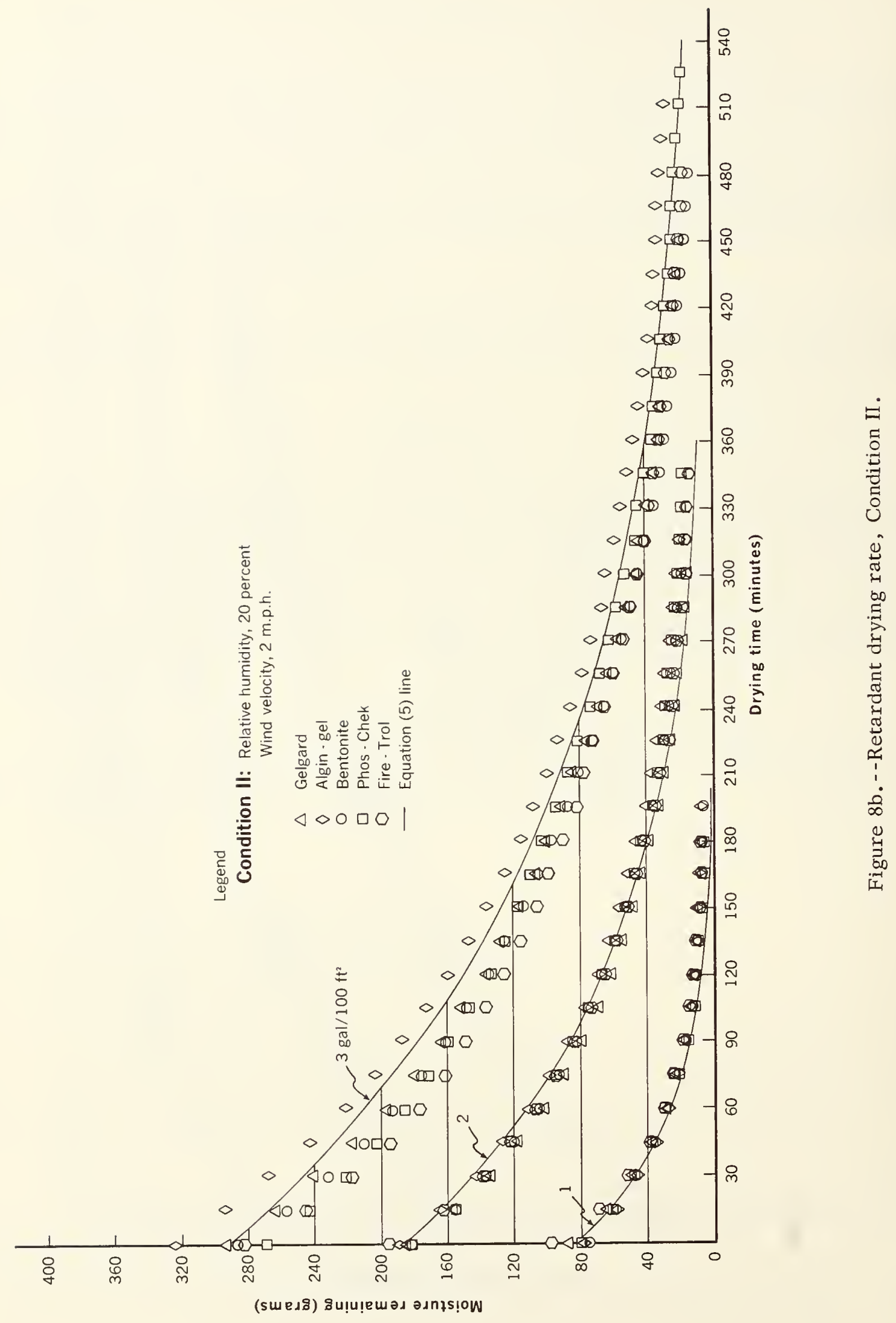



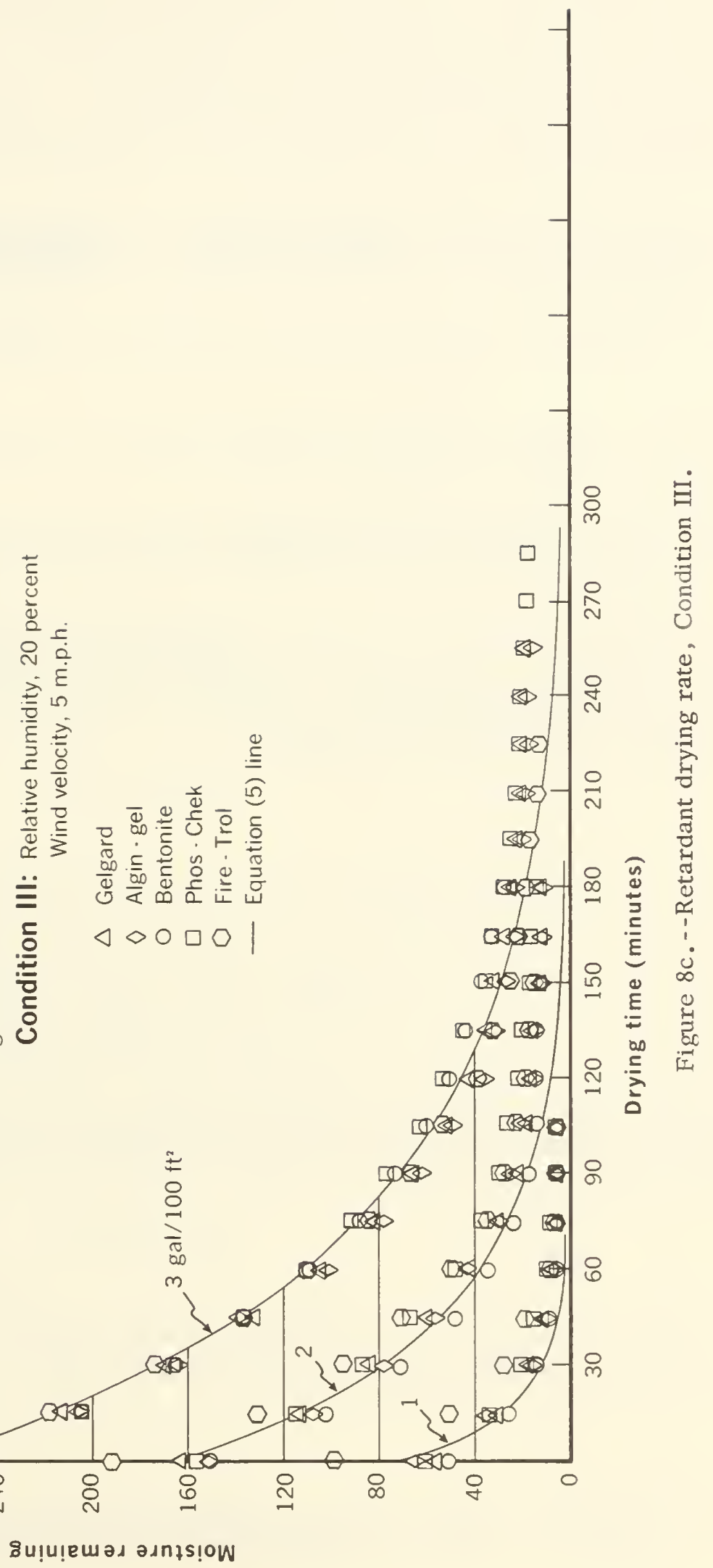
Retardants dry by a diffusion process that occurs at the interface between the retardant and the atmosphere. The amount of moisture that leaves the surface and goes into the atmosphere is proportional to the number of water molecules on the surface of the retardant and the environmental conditions that exist at the interface. Thus, $M$ in equation (2) depends upon the number of molecules on the surface of the retardant; and the constant $r$ depends upon the environmental conditions. The drying rate factor $r$ remains constant only for a constant condition.

All of the variables affecting retardant drying and all relations between these variables must be known in order to solve equation (2) from first principles. The experiments conducted in the wind tunnel, however, considered only three variables:

1. Area of retardant surface as controlled by amount of retardant applied to a uniform fuel bed.

2. Difference in vapor pressure between the retardant surface and the atmosphere as governed by relative humidity .

3. Air velocity in close proximity to the fuel bed as governed by wind-tunnel velocity blowing over uniform boundary conditions.

Equation (1) could not be derived from equation (2) and made completely general primarily because the actualvalue of the initial surface area of the retardant as it clung to the needles and bridged between them could not be determined. However, a satisfactory equation was obtained by considering the three variables tested that affect drying rate, and adjusting $r$ for each variable until a single value resulted.

\section{Surface Area}

The surface area of the retardant may be related to the amount of retardant applied uniformly and to the projected $a_{r e a}{ }^{8}$ over which it is spread. Consider a unit area of fuel bed (a cross section through the unit area is illustrated in figure 9); if a small amount of retardant is spread uniformly over each needle, it will be thin and will have a relatively large surface area. The maximum surface area possible is equal to that of the needles. As the amount of retardant is increased on the same unit area of fuel bed, liquid bridges form between the needles, and the surface area of the retardant decreases. The limiting value for maximum retardant and minimum surface area equals the projected unit area. This occurs when retardant is applied to fill all the crevices between the needles and only a flat surface of retardant is exposed. The drying rate constant $r$ will therefore be inversely proportional to the amount of retardant applied per unit area.

\section{Vapor Pressure}

The correction to the drying rate factor $r$ necessary to account for changes in humidity is provided by considering the difference in vapor pressure. Drying rate is proportional to the coefficient of diffusivity times the difference in vapor pressure between the surface of the retardant and the free stream:

${ }^{8}$ Projected area refers to the flat plane surface area considering the fuel bed to be twodimensional. 


\section{Cross Section of Needle Fuel Beds}

Figure 9.--Relation between surface area of retardant and amount of retardant applied to a unit area of fuel bed.
Case 1

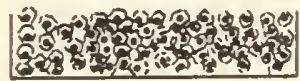

Maximum surface area
Case 2

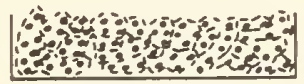

- fuel particle

surface of retardant

Case 1

Small amount of retardant applied uniformly over each needle produces maximum surface area.

Case 2

Additional retardant spread uniformly forms liquid bridges and reduces surface area of the retardant.

Gase 3

Limiting case, which is not achieved, would reduce surface area of retardant to the unit area of the fuel bed over which it is applied.

$$
r \approx K\left(p_{v_{0}}-p_{v_{1}}\right)
$$

where: $K=$ coefficient of diffusivity

$\mathrm{p}_{\mathrm{v}_{0}}=$ saturated vapor pressure at surface of the retardant

$\mathrm{p}_{\mathrm{v}_{1}}=$ partial pressure of the free stream water vapor.

Vapor pressure is determined by the temperature of the gas and the degree of saturation. The vapor pressure at the surface of the retardant may be taken for that of saturated air at the surface temperature $T_{0}$. $T_{0}$ may be obtained in two ways. As an approximation, the wet bulb temperature of the air may be used. For a more exact solution, use the equation

$$
T_{O}-T=\frac{K}{k} \frac{L}{c_{p}} \frac{\left(\rho_{W}-\rho_{o w}\right)}{\rho}
$$

which was developed for estimating the surface temperature of a raindrop ${ }^{9}$

${ }^{\ominus}$ Johnson, John C. Physical meteorology, p. 219, illus. New York: published jointly by Massachusetts Institute of Technology and John Wilson and Sons, Inc. 1954. 
where:

$$
\begin{aligned}
\mathrm{T}_{\mathrm{O}} & =\text { surface temperature of liquid }{ }^{\circ} \mathrm{C} \cdot{ }^{10} \\
\mathrm{~T} & =\text { free stream ambient temperature }{ }^{\circ} \mathrm{C} . \\
\mathrm{K} & =\text { diffusivity of water vapor in air } \mathrm{cm} \cdot 2 / \mathrm{sec} . \\
\mathrm{k} & =\text { thermal diffusivity } \mathrm{cm} \cdot{ }^{2} / \mathrm{sec} . \\
\mathrm{L} & =\text { latent heat of vaporization cal. } / \mathrm{g} \cdot \\
\mathrm{C}_{\mathrm{p}} & =\text { specific heat at constant pressure cal. } / \mathrm{g} \cdot{ }^{\circ} \mathrm{C} . \\
\rho_{\mathrm{W}} & =\text { ambient vapor density } \mathrm{g} \cdot / \mathrm{cc} \cdot \\
\rho_{\mathrm{OW}} & =\text { saturated vapor density } \mathrm{g} \cdot / \mathrm{cc} . \text { at surface of liquid } \\
\rho & =\text { density of air } \mathrm{g} \cdot / \mathrm{cc} .
\end{aligned}
$$

For condition I $\left(90^{\circ} \mathrm{F} ., 50\right.$-percent $\left.\mathrm{RH}\right)$ equation $(4)$ predicts $\mathrm{T}_{\mathrm{O}}=23.8^{\circ} \mathrm{C} .=75^{\circ} \mathrm{F}$. For conditions II and III $\left(90^{\circ} \mathrm{F} ., 20\right.$-percent $\left.\mathrm{RH}\right)$ equation (4) predicts $\mathrm{T}_{\mathrm{O}}=15^{\circ} \mathrm{C} .=59^{\circ} \mathrm{F}$. Having thus determined $\mathrm{T}_{\mathrm{O}}$, the saturated vapor pressure $\mathrm{p}_{\mathrm{O}}$ may be obtained from a steamtable. The free stream partial pressure of water vapor $p_{v_{1}}$ may be obtained by multiplying the saturated vapor pressure for the ambient temperature by the relative humidity. For condition I the difference in vapor pressure was $3.94 \mathrm{~mm}$. $\mathrm{Hg}$. For conditions II and III, the difference in vapor pressure $=5.56 \mathrm{~mm}$. Hg.

\section{Air Velocity}

Air flowing over the surface of the retardant accelerates the diffusion of water vapor between the retardant surface and the free stream air. Johnson indicates that the correction necessary is proportional to some function of the Reynolds number. The Reynolds number is the product of air density, air velocity, and a significant length of the system divided by the air viscosity. Air velocity was the only one of these variables changed during our tests. The drying rate factor $r$ was therefore assumed to be directly proportional to the air velocity above the fuel.

Figures $8 \mathrm{a}, 8 \mathrm{~b}$, and $8 \mathrm{c}$ were first plotted on semilog paper, and a straigh line fitted to each of the nine groups of data. The slope of each line gave nine values of the drying rate constant, which we shall designate $r_{O}$. Mathematically the modification of $r_{O}$ assumes the following form:

${ }^{10}$ Constants for use in equation (4) may be found in table 7.3 of Physical Meteorology, by Johnson (see footnote 9). For a complete solution of the equation, a table of temperature versus vapor density must be used. Such a table is available in handbooks of meteorology. The metric system is used in the retardant drying section of this report because most handbook constants are in this system. The remainder of the report is in the more familiar English units. 
let $r^{\prime}=r_{0}$ corrected for surface area

$$
r^{\prime}=r_{0} w_{0}
$$

where $\mathrm{w}_{\mathrm{O}}=$ amount of retardant applied per unit area

let $r^{\prime \prime}=r_{0}$ corrected for surface area and vapor pressure

$$
r^{\prime \prime}=\frac{r_{0} w_{0}}{p_{v_{0}}-p_{v_{1}}}
$$

where $\mathrm{p}_{\mathrm{v}_{\mathrm{O}}}=$ vapor pressure at surface of retardant

$\mathrm{p}_{\mathrm{v}_{1}}=$ vapor pressure in free stream atmosphere

let $r=r_{0}$ corrected for surface area, vapor pressure and air velocity

$$
r=\frac{\left.r_{o_{0}} w_{v_{0}}-p_{v_{1}}\right)}{U\left(p_{v_{0}}\right.}
$$

where $\quad U=$ air velocity above fuel bed.

Numerical values for these corrections are shown in table 4 . The resulting average value of $r$ is $1.14 \times 10^{-6}$. Inserting the corrections for $r_{O}$ and the new value of $r$, equation (2) becomes:

$$
\mathrm{M}=\mathrm{M}_{\mathrm{O}} \exp -1.14 \times 10^{-6} \frac{\mathrm{U}\left(\mathrm{p}_{\mathrm{v}_{\mathrm{O}}}-\mathrm{p}_{\mathrm{v}_{1}}\right) \mathrm{t}}{\mathrm{w}_{\mathrm{O}}}
$$

where $\quad M=$ amount at any time, grams ${ }^{11}$

${ }^{11} \mathrm{M}$ will assume the units of $\mathrm{M}_{\mathrm{O}} \cdot \mathrm{M}_{\mathrm{O}}$ may be in total values such as pounds or grams or

\begin{tabular}{|c|c|c|c|c|c|c|c|c|c|c|}
\hline $\begin{array}{l}\text { Condi- } \\
\text { tion }\end{array}$ & $\begin{array}{l}\text { : Amount : } \\
\text { : gal./100: } \\
\text { : sq.ft. : }\end{array}$ & $r_{0}$ & $\begin{array}{cc}: & \mathrm{M}_{\mathrm{O}} \\
: & \text { grams }\end{array}$ & $\begin{array}{l}\overline{\mathrm{w}}_{\mathrm{o}} \\
\mathrm{g} / \mathrm{cm} .^{2}\end{array}$ & $\begin{array}{ll}: & \\
: & \quad \\
& \end{array}$ & $\begin{array}{l}: \\
: \quad \text { Ave. r' } \\
:\end{array}$ & $\begin{array}{l}: \mathrm{pv}_{\mathrm{O}}-\mathrm{p}_{\mathrm{v}_{1}}: \\
: \mathrm{mm} \cdot \mathrm{Hg} \cdot \\
:\end{array}$ & $r^{\prime \prime}$ & $\begin{array}{ll}: & \text { U } \\
: & :\end{array}$ & r \\
\hline I & $\begin{array}{l}1 \\
2 \\
3\end{array}$ & $\begin{array}{r}0.010950 \\
.005513 \\
.003633\end{array}$ & $\begin{array}{r}97.46 \\
204.34 \\
318.40\end{array}$ & $\begin{array}{r}0.03497 \\
.07332 \\
.11420\end{array}$ & $\begin{array}{l}3.829 \times 10^{-4} \\
4.042 \times 10^{-4} \\
4.149 \times 10^{-4}\end{array}$ & $4.007 \times 10^{-4}$ & 3.94 & $1.017 \times 10^{-4}$ & 89.4 & $1.138 \times 10^{-6}$ \\
\hline II & $\begin{array}{l}1 \\
2 \\
3\end{array}$ & $\begin{array}{l}.018350 \\
.008600 \\
.005830\end{array}$ & $\begin{array}{r}84.32 \\
186.72 \\
290.94\end{array}$ & $\begin{array}{l}.03027 \\
.06703 \\
.10440\end{array}$ & $\begin{array}{l}5.554 \times 10^{-4} \\
5.764 \times 10^{-4} \\
6.068 \times 10^{-4}\end{array}$ & $5.800 \times 10^{-1}$ & 5.56 & $1.043 \times 10^{-4}$ & 89.4 & $1.167 \times 10^{-\epsilon}$ \\
\hline III & $\begin{array}{l}1 \\
2 \\
3\end{array}$ & $\begin{array}{l}\text { not used } \\
.022270 \\
.015360\end{array}$ & $\begin{array}{r}65.52 \\
161.28 \\
268.00\end{array}$ & $\begin{array}{l}.02352 \\
.05790 \\
.09621\end{array}$ & $\begin{array}{c}1.289 \times 10^{-3} \\
1.478 \times 10^{-3}\end{array}$ & $1.38 \times 10^{-3}$ & 5.56 & $2.489 \times 10^{-4}$ & 223.5 & $1.114 \times 10^{-6}$ \\
\hline
\end{tabular}
gallons, or it may be in unit values such as grams per square centimeter, pounds per square foot, or gallons per hundred square feet.

Table 4.--Determination of drying rate factor $r$ 


$$
\begin{aligned}
\mathrm{M}_{\mathrm{O}} & =\text { initial application amount, grams } \\
\mathrm{U} & =\text { air velocity at surface of fuel bed, cm. } / \mathrm{sec} . \\
\mathrm{p}_{\mathrm{V}_{\mathrm{O}}} & =\text { vapor pressure at surface of retardant, } \mathrm{mm} . \mathrm{Hg} \\
\mathrm{p}_{\mathrm{V}_{\mathrm{l}}} & =\text { partial pressure of moisture in free stream air, } \mathrm{mm} . \mathrm{Hg} \\
\mathrm{t} & =\text { time of drying, minutes } \\
\mathrm{w}_{\mathrm{O}} & =\text { initial application concentration, grams } / \mathrm{cm} .{ }^{2} .
\end{aligned}
$$

The lines through the data points (fig. 8) are computed from equation (5). The lines fit the data until the point on the curve where the retardant is nearly dry. As explained, this is believed to result from the depletion of water on the surface of the needles and slower evaporation of moisture from within the needles.

On fine or closely spread fuels such as brush, grass, ground litter, or logging slash, equation (5) provides a good estimate of how much moisture will remain on the treated fuel after drying in a known environment. Logs or other large fuels present a different problem. Equation (5) may also be used to predict effective holding time of short-term retardants by incorporating into the equation an expression for the amount of total moisture required for effective retardation.

\section{Effective Holding Time--Short-Term Retardants}

Short-term retardants derive their fire-inhibiting powers from the water they contain. This water, when applied onto a fuel, must evaporate or be driven off by the heat of the fire before the fuel's temperature can be raised to ignition point. Twenty to 22 percent is the generally accepted limit of fuel moisture that will permit combustion in dead fuels without forced convection. Taking the limit of fuel moisture to be at least 22 percent, an expression can be developed for the minimum amount of short-term retardant necessary to be effective against a fire.

Let $\mathrm{G}=$ minimum amount of retardant per unit area necessary for effective retardation,

$$
\begin{aligned}
& \mathrm{w}_{\mathrm{f}}=\text { amount of dead fuel per unit area, and } \\
& \mathrm{M}_{\mathrm{f}}=\text { fuel moisture content, percent, }
\end{aligned}
$$

then: $\quad G=w_{f}\left(.22-M_{f}\right)$

$\mathrm{G}$ and $\mathrm{w}_{\mathrm{f}}$ must be in the same units such as $\mathrm{lb} . / \mathrm{sq}$. $\mathrm{ft}$., or a conversion constant must be included in the equation.

The equation for retardant drying rate (5) may now be combined with the amount of moisture necessary, equation 6 , to estimate the effective time of short-term retardants. The expression for $G$ in equation (6) is substituted for $M$ in equation (5). The initial amount of retardant $\mathrm{M}_{\mathrm{O}}$ is changed from total amount to the amount per unit area, and the units are converted to those in general fire control use, resulting in equation (7). 
$\mathrm{w}_{\mathrm{f}}\left(.22-\mathrm{M}_{\mathrm{f}}\right)=1.96 \exp -\left[\frac{0.0307 \mathrm{U}\left(\mathrm{p}_{\mathrm{v}_{\mathrm{o}}}-\mathrm{p}_{\mathrm{v}_{1}}\right) \mathrm{t}}{\mathrm{G}_{\mathrm{O}}}\right]$

where

$\mathrm{M}_{\mathrm{f}}=$ fuel moisture content, ratio of moisture to dry weight of fuel

$\mathrm{w}_{\mathrm{f}}=$ fuel loading dry weight, tons/acre

$\mathrm{G}_{\mathrm{O}}=$ initial retardant concentration, gal./100 sq.ft.

$\mathrm{U}=$ windspeed at 1 -foot level, m.p.h.

$\mathrm{p}_{\mathrm{v}_{\mathrm{O}}}=$ vapor pressure at surface of retardant, in $\mathrm{Hg}$

$\mathrm{p}_{\mathrm{v}_{1}}=$ partial pressure of water vapor in air at ambient dry bulb temperature and humidity, $\mathrm{p}_{\mathrm{v}_{1}}=$ (relative humidity) $\times$ (saturated vapor pressure) , in $\mathrm{Hg}$

$\mathrm{t}=$ effective time of retardant, minutes

Equation (7) may be rearranged to solve directly for effective holding time of the retardant.

$$
t=\frac{G_{0} \log _{e}\left[\frac{w_{f}\left(.22-M_{f}\right)}{1.96 G_{o}}\right]}{-0.0307 U\left(p_{v_{o}}-p_{v_{1}}\right)}
$$

where $\log _{e}$ indicates natural logarithm or logarithm to the base e. Equation (7.1) can now be solved directly for length of holding time if the environmental conditions and fuel conditions are known or can be approximated. As an example, assume:

$$
\begin{aligned}
\mathrm{M}_{\mathrm{f}}= & 0.05 \mathrm{lb} \cdot / \mathrm{lb} . \\
\mathrm{w}_{\mathrm{f}}= & 14.5 \text { tons } / \text { acre, dry weight of fuel } \\
\mathrm{G}_{\mathrm{O}}= & 3 \mathrm{gal} . / 100 \mathrm{sq} . \mathrm{ft} ., \text { case } 1 \\
& 2 \text { gal./100 sq.ft., case } 2 \\
\mathrm{U}= & 5 \mathrm{~m} \cdot \mathrm{p} \cdot \mathrm{h} . \text { at } 1 \text {-foot level } \\
\mathrm{T}_{\mathrm{amb}}= & 90^{\circ} \mathrm{F} . \\
\mathrm{RH}= & 50,20,10, \text { and } 5 \text { percent }
\end{aligned}
$$

Substitution in equation (7.1) gives effective retardant durations, which are plotted in figure 10.

\section{Limitations of Short-Term Retardant Effective Time Equation}

Equation (7) is an empirical equation that was developed for fine dead fuels arranged in a random fuel bed. No consideration has been given for the increased drying rate which would 


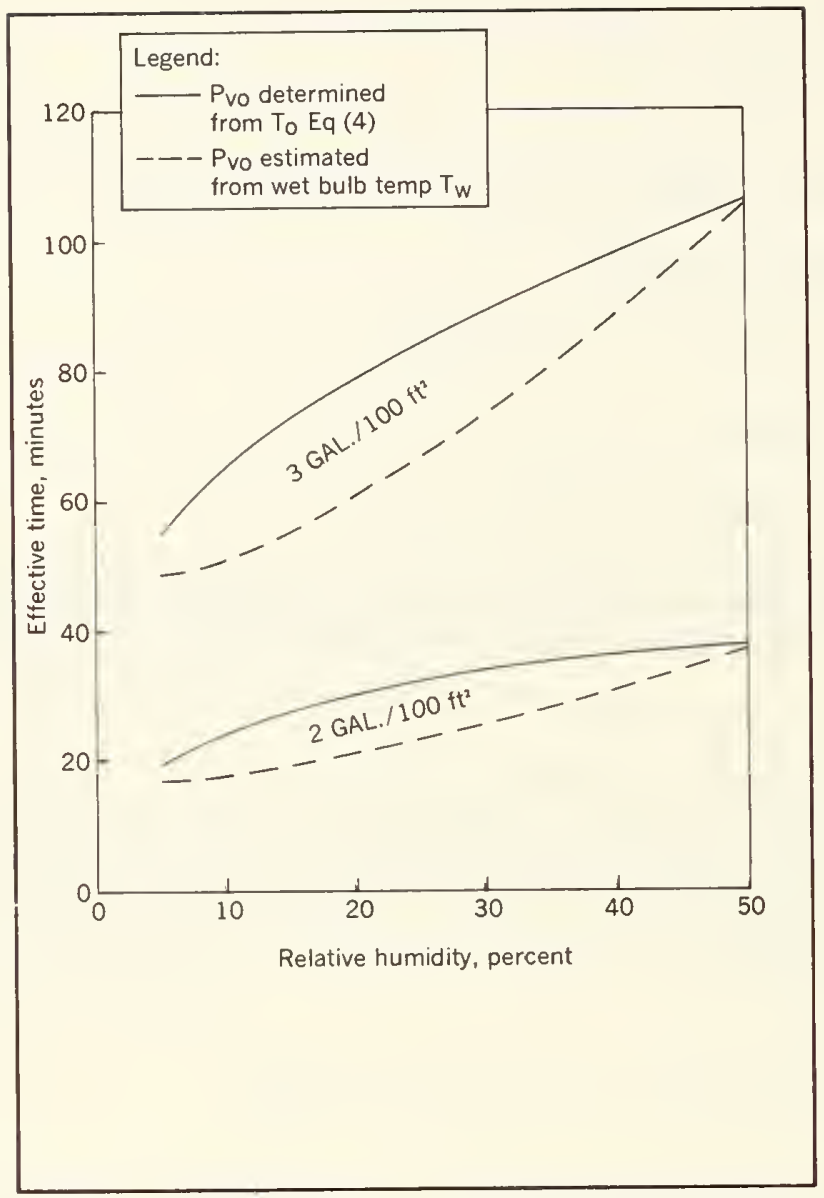

Figure 10.--Short-term retardant-an example of effective holding time. Assume: Windspeed $=5$ $\mathrm{m} . \mathrm{p} . \mathrm{h}$. at $1-\mathrm{ft}$. level, Temp.= $90^{\circ} \mathrm{F} ., \quad$ Fuel loading $=14.5$ tons/acre.

result from solar radiation or the close proximity of a fire. Equation (7) will, therefore, produce the longest holding time that could be expected, and the effective times shown in figure 10 would be considerably shortened in direct sunlight or near a fire.

\section{Burning Test}

Rate of spread, rate of weight loss, and the radiant flux to an overhead radiometer from each fire were measured. Rate of spread, however, was the only variable used in analyzing the results of the fires. Rate of weight loss and irradiance supported the rate-of-spread data, but tended to be misleading because of the afterburning that often occurred well behind the leading edge of the fire. A " $t$ " test was used to check the significance of changes in environmental conditions, amount of retardant, and drying time on all of the data. Complete results of the " $t$ " test are given in tables 8-11 (Appendix).

Tables 5 and 6 summarize the rate-of-spread data. Each number cited in the table is the average of three or more tests conducted at the stated combination of environmental condition, retardant amount, and degree of dryness. Using this information plus the initial fuel moisture and the water content in the retardant mixture, we calculated the total amount of moisture remaining in the fuel bed at the time of ignition. 

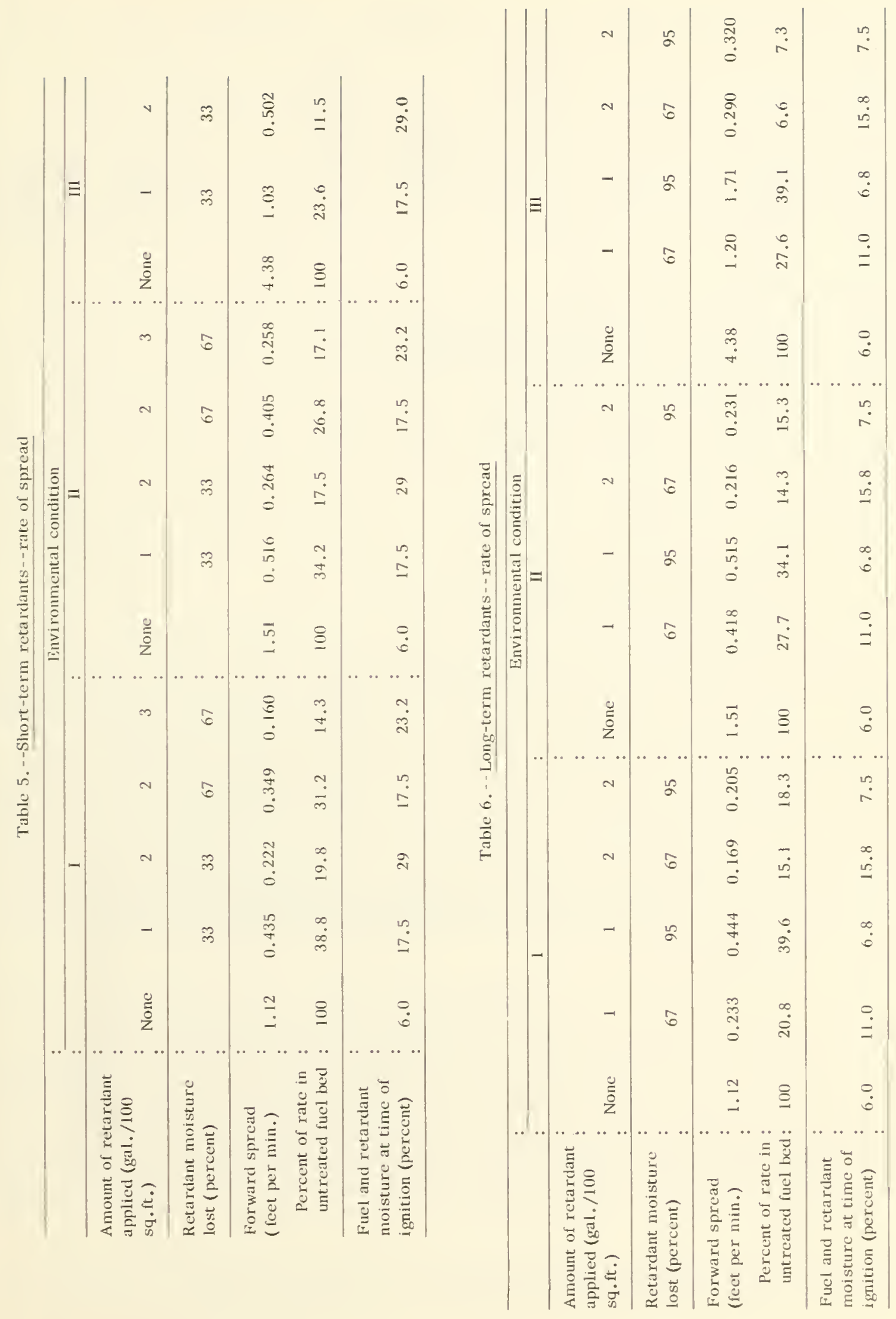


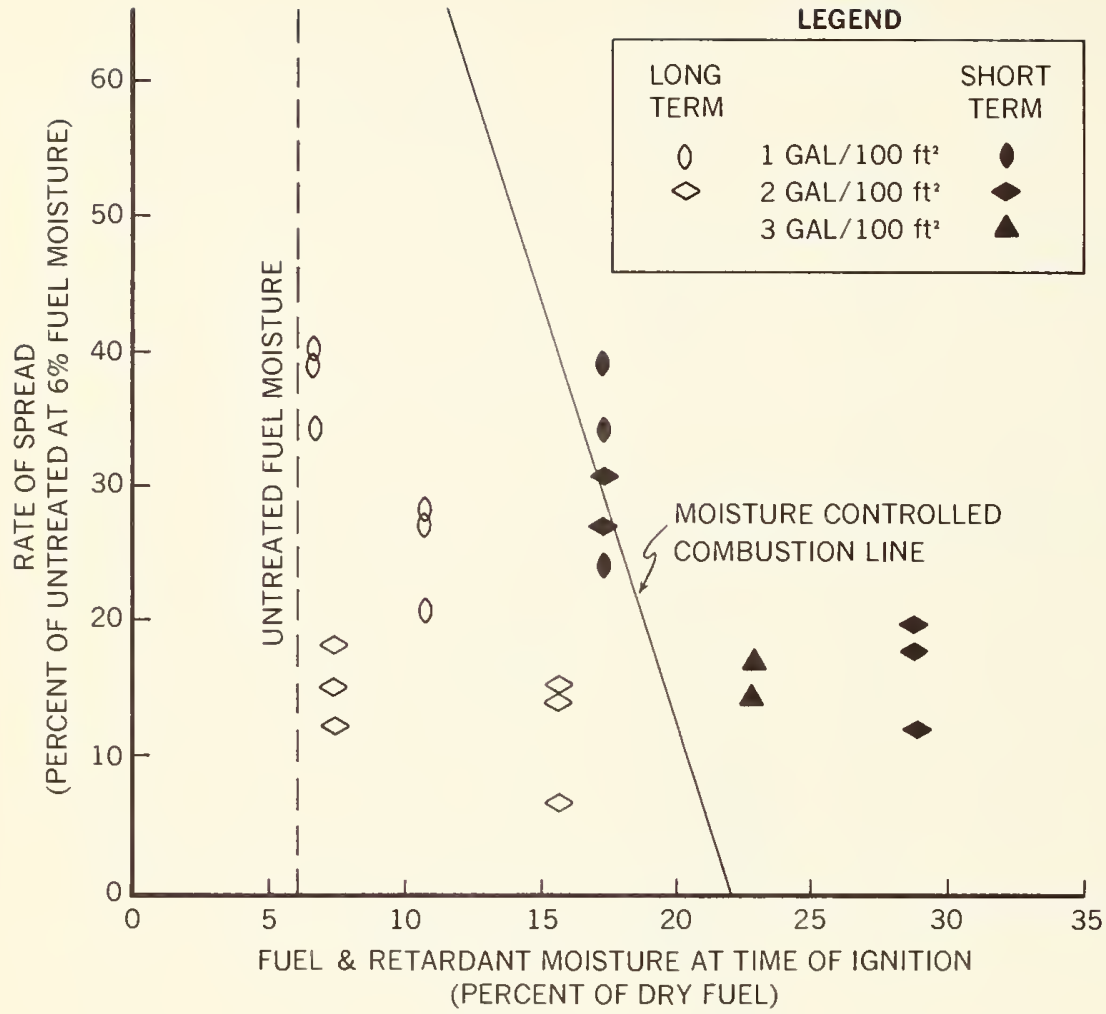

Figure 11.--Effect of total moisture on rate of spread.

The effect of total moisture upon rate of spread is shown in figure 11 . Each point is the average of three or more tests. The spread in data is a result of burning in three environmental conditions. Total moisture is shown as a percent of the dry fuel weight. Rate of spread is shown as a percent of the rate that would occur in an untreated fuel bed at 6-percent moisture content. A line showing the relation between rate of spread and fuel moisture content in untreated fuel beds is shown for comparison with the data points. Data for this line were obtained from previous study of untreated beds. ${ }^{12}$ One-hundred-percent rate of spread was taken at 6percent fuel moisture, and any other rate along the line is based on the 6-percent value. The comparisons of fire retardants were made on this same basis. Note that the line passes through some of the short-term retardant points and intercepts the fuel moisture coordinate at 22 percent, which was the moisture level used to calculate the effective holding time of short-term retardants in equations 6 and 7 .

Refer to figure 11 and note that the short-term retardants are designated by solid symbols and long-term retardants by open symbols. The shape of the symbols designates whether 1,2 , or 3 gal./100 sq.ft. were applied initially. Some interesting conclusions can be drawn from studying figure 11. Data points that fall below 20 percent of the untreated rate of spread were characterized by smoldering combustion; they burned deep in the fuel bed where the retardant had not penetrated. Fuel beds treated with short-term retardant required total fuel moistures greater than the 22-percent fuel moisture limit to suppress the flaming surface fire. When total fuel moisture of the short-term retardant-treated fuel beds was less than 22 percent, the rate of spread began to follow the flaming combustion line of untreated fuel beds at the same

\footnotetext{
12 Rothermel and Anderson, op. cit., p. 3.
} 
moisture content. This behavior substantiates the theory that the effective holding time of short-term retardants is limited only by the total amount of moisture on the fuel.

No such limitation exists for the long-term retardant. When the total moisture content was reduced to within 1 or 2 percent of the untreated fuel moisture level (dashed line, fig. 11), the rate of spread was still well below the rate of spread for untreated fuel at the same moisture level. Thus the limitations of solar heating and fire heating mentioned earlier will not shorten the effective holding time of long-term retardants as they would short-term retardants These facts should be considered seriously in the purchase of retardants, together with relative costs of short-term and long-term retardants.

The effect of initial application amount of long-term retardants is shown in figure 12 , where the actual rate of spread is plotted against an approximation of the equivalent National Spread Index. The data now separate and align and best illustrate the effect of initial application amount and retardant drying. Note the marked difference in slope of the lines for initial application amounts of $1 \mathrm{gal} . / 100 \mathrm{sq} . \mathrm{ft}$. and $2 \mathrm{gal} . / 100 \mathrm{sq} . \mathrm{ft}$. For the fuel loading used, an initial concentration of 1 gal./100 sq. ft. was not sufficient to effectively retard the fire. The rate of spread increased sharply with both Spread Index and retardant dryness. However, when the concentration is doubled, it can be seen to be effective even though the Spread Index increases and the retardant loses 95 percent of its moisture. Whatever fire propagation occurred when 2 gal./100 sq.ft. was applied took place near the bottom of the fuel bed, where the retardant did not penetrate.

The "t" tests confirm these observations. Drying time was significantly different when only 1 gal./100 sq.ft. was applied, but was not significant when 2 gal./100 sq.ft. were applied. Where 2 gal./100 sq.ft. were initially applied and the long-term retardant was fully dry (95 percent), the difference due to environment was not significant. In every case, a high significance level was found for differences in initial application amount.

This result should not be entirely unexpected since the long-term retardant contains a fire-inhibiting salt which must contact the fuel if it is to alter the combustion characteristics of the fuel. A certain minimum ratio of retardant to fuel may be expected to exist, and applications below this amount should not be expected to provide sufficient treatment to enough fuel to be effective in suppressing the fire. Our work indicates the ratio for the initial amount of long-term retardant is near 0.4 pound of retardant per pound of dead fuel. This ratio should, of course, be put in terms of the necessary ratio of retardant salt to dry fuel required to hold a fire. Such a ratio would provide a basis of comparison for long-term retardants.

\section{CONCLUSIONS}

1. All five of the retardants tested had similar drying rates within each of nine drying combinations.

2. Rates of spread in fuel beds treated with long-term retardants were well below the value which might be expected if moisture alone were causing the effectiveness. In contrast, rate of spread in fuels treated with short-term retardants appears to depend entirely upon total moisture retained.

3. Long-term retardants are effective even after their moisture has evaporated when the initial amount of retardant is sufficient. Short-term retardants remain effective only when the moisture retained around or in the fuel is at least 22 percent of the dry weight of the fuel. 


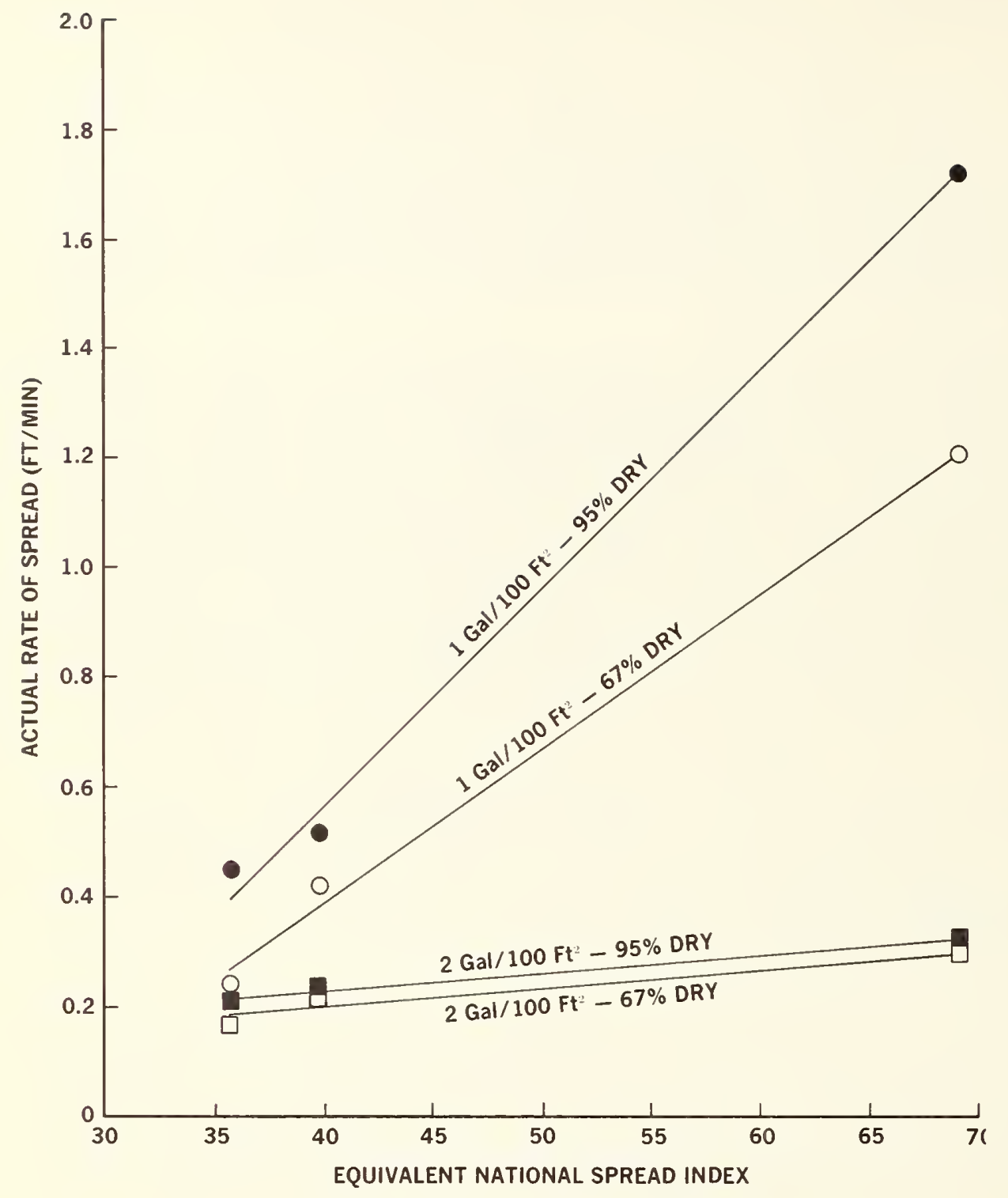

Figure 12,-- Influence of concentration and dryness upon rate of spread of long-te $\mathrm{rm}$ retardant.

4. The maximum length of time that a short-term retardant can effectively "hold" a fire can be predicted by equation (7):

$$
\mathrm{w}_{\mathrm{f}}\left(.22-\mathrm{M}_{\mathrm{f}}\right)=1.96 \exp \frac{-0.0307 \mathrm{U}\left(\mathrm{p}_{\mathrm{v}_{\mathrm{O}}}-\mathrm{p}_{\mathrm{v}_{1}}\right) \mathrm{t}}{\mathrm{G}_{\mathrm{O}}}
$$

This holding time may be extremely short when the retardant is subjected to low humidity, moderate airflow, exposure to sunlight, and radiant or convective heating by flames.

5. A certain minimum ratio, by weight, of long-term retardant to fuel appears necessary for best results. Laboratory tests indicate the ratio is near 0.4 . Ultimately this ratio will have to be associated with actual weight of salt remaining instead of total weight of solution applied. 


\section{APPENDIX}

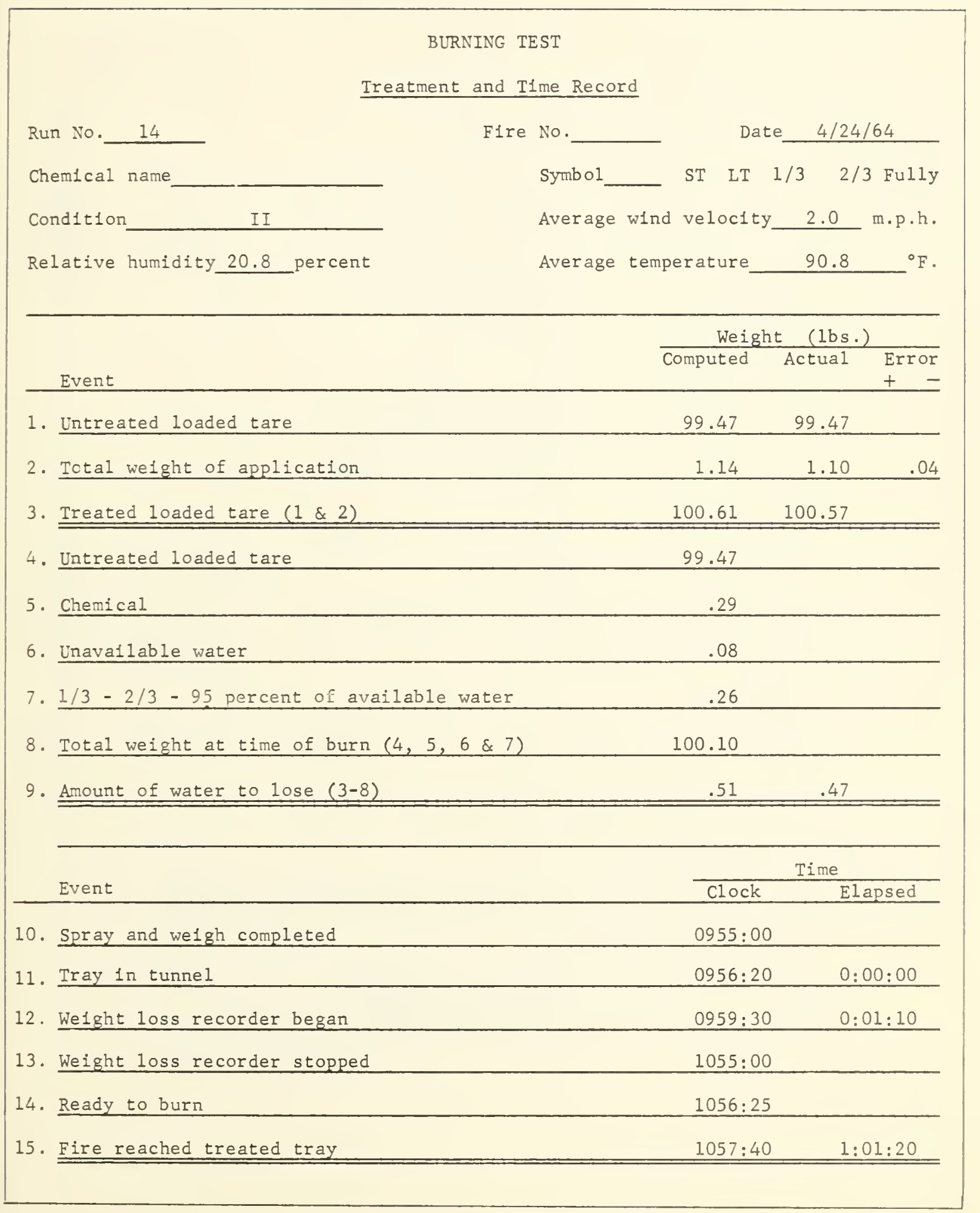

Figure 13.--Sample treatment and time record sheet. 
Table 7. - $\frac{\text { Technical mixing data }}{\text { ' }}$

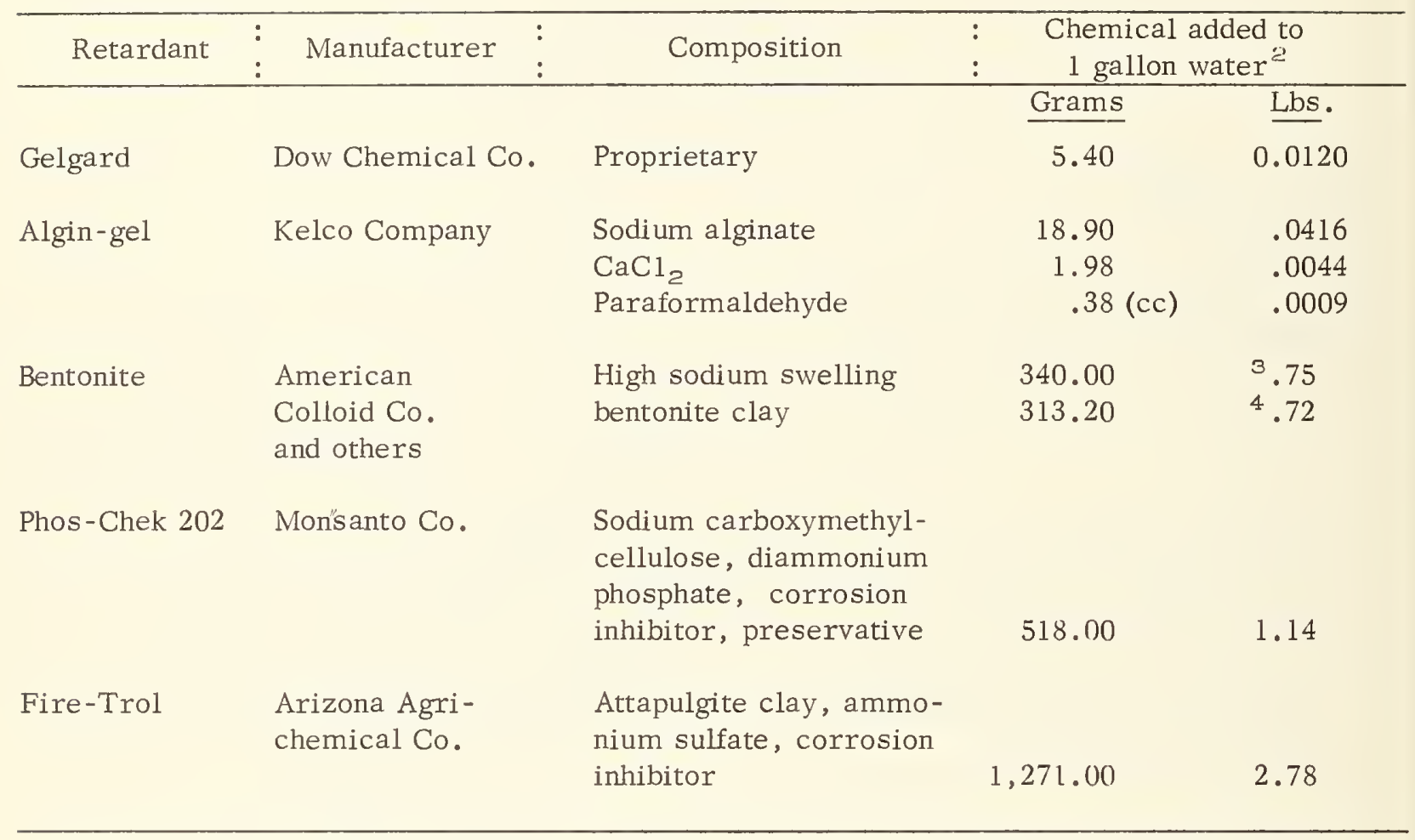

1 Materials are mixed in amounts generally according to information in "Chemicals for Forest Fire Fighting," NFPA, 1963.

2 Directions for mixing:

1. Water used is local well water, except for mixing Gelgard, which requires distilled water; water should be $73^{\circ} \mathrm{F}$.

2. All mixing reported here was done with the Pacific Southwest Forest and Range Experiment Station's high-shear impeller driven at 2,380 r.p.m.

3. Viscosity should be determined by the following procedure, using Brookfield model LVF viscometer, at spindle speed of $60 \mathrm{r.p.m.:}$

a. Mix and let stand at least 18 hours. Record mixture temperature.

b. Slosh container around for 20 seconds and fill a 1,000-ml. beaker.

c. Let mixture stand 3 minutes.

d. Run viscometer 1 minute, then take 3 readings.

e. Raise spindle out, stir mildly and replace spindle.

f. Repeat viscometer run as in (d) and (e) above.

g. Repeat (e) and (f) above: will make 3 runs of 3 readings each.

${ }^{3}$ Drying test.

4 Burning test. 
Table 8.--"t" test for amount of retardant

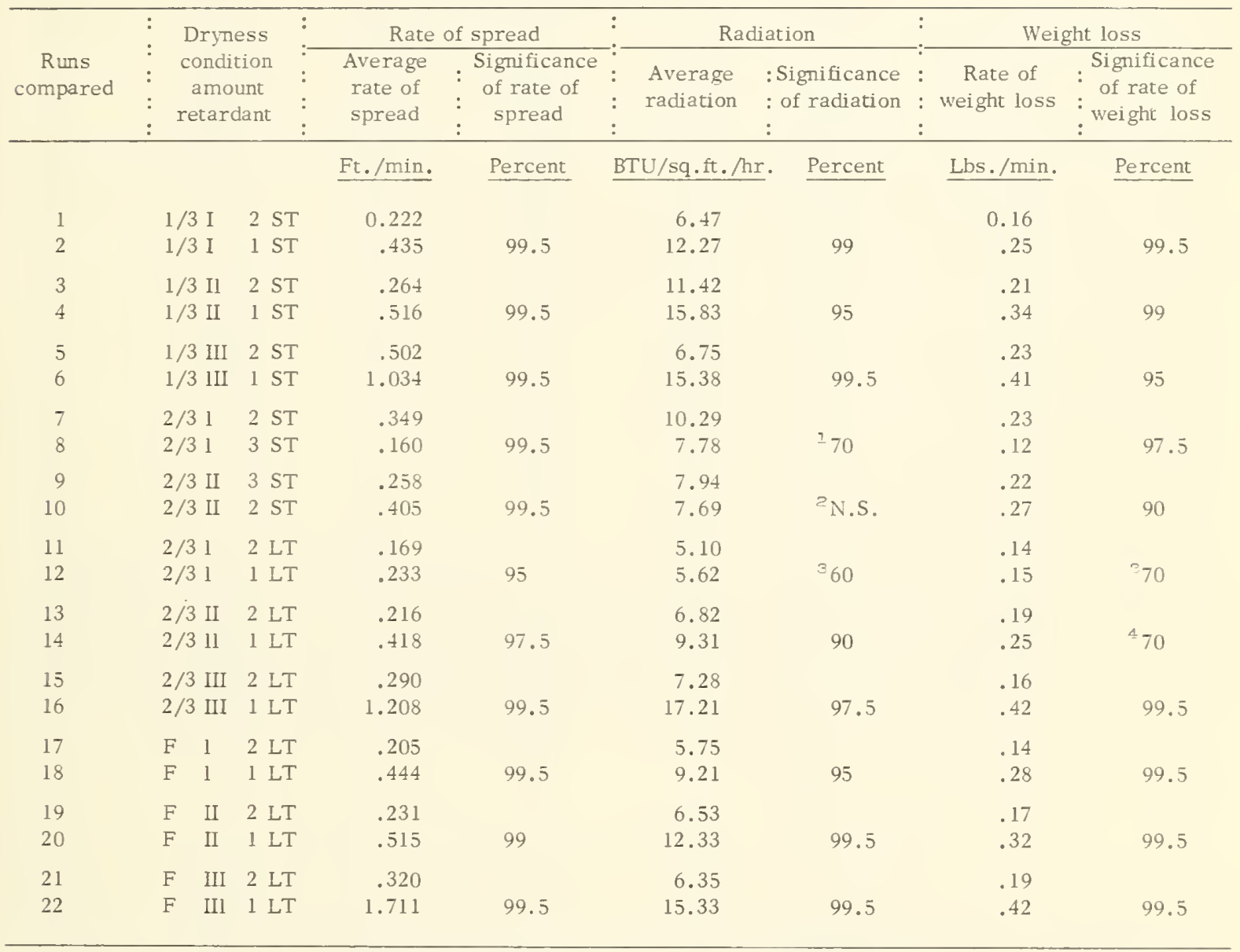

${ }^{2}$ Variation within runs is large and reduces the significance. $\mathrm{Sm}_{7}$ and $\mathrm{Sm}_{8}=2.03 ; \mathrm{S}_{7}$ and $\mathrm{S}_{8}=4.17$.

${ }^{2}$ The rate of $3 \mathrm{gal} . / 100 \mathrm{sq}$. $\mathrm{ft}$. Shows greater radiation than the rate of 2 gals./100 sq. ft. Run 10 had no peaks or humps in radiometer, while run 9 had peaks in all fires. Radiation in 10 is probably low, as supported by the fact run 7 had higher radiation and was the same except it was condition 1 instead of 11 .

${ }^{3}$ In run 11, all three fires had large peaks, while in run 12 the fires had no peaks, probably making the radiation and weight loss high. Also, in run 12 one fire had a radiation of 3.9 , pulling down the average radiation and increasing the sums of squares. $\mathrm{S}=2.02$ and $\mathrm{Sm}=1.17$.

${ }^{4}$ The significance is low because the variation within values ranges from .15 to .44 in run $14 . \quad \mathrm{S}=.15$ and $\mathrm{Sm}=.09$. $\mathrm{S}$ is greater than the difference between runs 13 and 14 . 
Table 9. - " $t$ " test for environmental conditions

\begin{tabular}{|c|c|c|c|c|c|c|c|c|c|}
\hline \multirow[b]{2}{*}{$\begin{array}{c}\text { Runs } \\
\text { compared }\end{array}$} & \multirow{2}{*}{\multicolumn{2}{|c|}{ 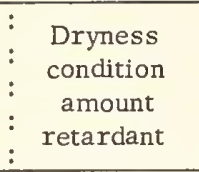 }} & \multirow[b]{2}{*}{$\begin{array}{l}: \\
\vdots \\
:\end{array}$} & \multicolumn{2}{|c|}{ Rate of spread } & \multicolumn{2}{|c|}{ Radiation } & \multicolumn{2}{|c|}{$: \quad$ Weight loss } \\
\hline & & & & $\begin{array}{l}\text { Average } \\
\text { rate of } \\
\text { spread }\end{array}$ & $\begin{array}{c}\text { Significance } \\
: \text { of rate of } \\
\text { spread }\end{array}$ & $\begin{array}{c}\text { Average } \\
\text { radiation }\end{array}$ & $\begin{array}{l}: \text { Significance } \\
: \text { of radiation } \\
:\end{array}$ & $\begin{array}{l}\text { Rate of } \\
: \text { weight loss } \\
\end{array}$ & $\begin{array}{l}\text { Significance } \\
\text { of rate of } \\
: \text { weight loss }\end{array}$ \\
\hline & & & & Ft./min. & $\underline{\text { Percent }}$ & $\mathrm{BTU} / \mathrm{sq} . \mathrm{ft} . / \mathrm{hr}$ & Percent & Lbs./min. & $\underline{\text { Percent }}$ \\
\hline 1 & $1 / 3 \mathrm{I}$ & $2 \mathrm{ST}$ & & 0.222 & & 6.47 & & 0.16 & \\
\hline 3 & $1 / 3$ II & $2 \mathrm{ST}$ & & .264 & 97.5 & 11.42 & 99 & .21 & 99.5 \\
\hline 2 & $1 / 3 \mathrm{I}$ & $1 \mathrm{ST}$ & & .435 & & 12.27 & & .25 & \\
\hline 4 & $1 / 3 \mathrm{II}$ & $1 \mathrm{ST}$ & & .516 & 97.5 & 15.83 & 90 & .34 & 95 \\
\hline 3 & $1 / 3 \mathrm{II}$ & $2 \mathrm{ST}$ & & .264 & & 11.42 & & .21 & \\
\hline 5 & $1 / 3$ III & $2 \mathrm{ST}$ & & .502 & 97.5 & 6.75 & $* 199$ & .23 & ${ }^{1} 60$ \\
\hline 4 & $1 / 3 \mathrm{II}$ & $1 \mathrm{ST}$ & & .516 & & 15.83 & & .34 & \\
\hline 6 & $1 / 3 \mathrm{III}$ & $1 \mathrm{ST}$ & & 1.034 & 99.5 & 15.38 & ${ }^{2}$ N.S. & .41 & ${ }^{2}$ N.S. \\
\hline 7 & $2 / 3 \mathrm{I}$ & $2 \mathrm{ST}$ & & .349 & & 10.29 & & .23 & \\
\hline 10 & $2 / 3$ II & $2 \mathrm{ST}$ & & .405 & 80 & 7.69 & *3 80 & .27 & 80 \\
\hline 8 & $2 / 3 \mathrm{I}$ & $3 \mathrm{ST}$ & & .160 & & 7.78 & & .12 & \\
\hline 9 & $2 / 3 \mathrm{II}$ & $3 \mathrm{ST}$ & & .258 & 99.5 & 7.94 & ${ }^{4}$ N.S. & .22 & 90 \\
\hline 11 & $2 / 3$ I & $2 \mathrm{LT}$ & & .169 & & 5.10 & & .14 & \\
\hline 13 & $2 / 3$ II & $2 \mathrm{LT}$ & & .216 & 90 & 6.82 & 90 & .19 & 90 \\
\hline 12 & $2 / 3 \mathrm{I}$ & $1 \mathrm{LT}$ & & .233 & & 5.62 & & .15 & \\
\hline 14 & $2 / 3$ II & $1 \mathrm{LT}$ & & .418 & 95 & 9.31 & 90 & .25 & 80 \\
\hline 13 & $2 / 3$ II & $2 \mathrm{LT}$ & & .216 & & 6.82 & & .19 & \\
\hline 15 & $2 / 3$ III & $2 \mathrm{LT}$ & & .290 & 90 & 7.28 & ${ }^{5}$ N.S. & .16 & $* 580$ \\
\hline 14 & $2 / 3$ II & $1 \mathrm{LT}$ & & .418 & & & & .25 & \\
\hline 16 & $2 / 3$ III & $1 \mathrm{LT}$ & & 1.208 & 99.5 & 17.21 & 90 & .42 & 90 \\
\hline 17 & F I & $2 \mathrm{LT}$ & & .205 & & 5.75 & & .14 & \\
\hline 19 & F II & $2 \mathrm{LT}$ & & .231 & 80 & 6.53 & 80 & .17 & 80 \\
\hline 18 & F I & $1 \mathrm{LT}$ & & .444 & & 9.21 & & .28 & \\
\hline 20 & F II & $1 \mathrm{LT}$ & & .515 & 90 & 12.33 & 95 & .32 & 90 \\
\hline 19 & $\mathrm{~F} \quad$ II & $2 \mathrm{LT}$ & & .231 & & 6.53 & & .17 & \\
\hline 21 & F III & $2 \mathrm{LT}$ & & .320 & 80 & 6.35 & ${ }^{6}$ N.S. & .19 & 670 \\
\hline 20 & F II & $1 \mathrm{LT}$ & & .515 & & 12.33 & & .32 & \\
\hline 22 & F III & $1 \mathrm{LT}$ & & 1.711 & 90 & 15.33 & 99.5 & .42 & 99.5 \\
\hline
\end{tabular}

*Significance in the reverse direction.

${ }^{1}$ It appears that data from these two fires are acceptable, the variation being relatively small. It appears the condition of run 5 is critical in that the main agent in the rate of spread is spotting, probably due to the increased wind in condition III. Because of this, the radiation is significantly lower, and the rate of weight loss is not significantly different.

${ }^{2}$ Run 6 again spotted, smoldered, dried out, and then burned more intensively. The radiation charts show a continuous increase in the radiation from 5 to 7 feet in all fires of run 6 . In run 4 the radiation is more uniform, not showing the obvious increase from 5 to 7 feet. The averages thus are not significantly different. Because of a large variation in run 6 rate of weight loss, there shows no significant difference between runs 4 and 6 rate of weight loss.

${ }^{3}$ Variation was great, more afterburning occurred in run 7 , possibly giving a high average radiation. The fires in run 10 had very little afterburn, thus the probable reason for a lower radiation.

${ }^{4}$ Run 9 fires were very sporadic in their burning pattern. Areas of low radiation and large peaks occurred. Run 8 was much more consistent, variation within also exceeded the variation in between .

${ }^{5}$ Variation is large in both radiation and rate of weight loss. One fire of run 15 with a .10 rate of weight loss is obviously low. Also, since rate of spread was by large fingers, the readings between 3 and 5 feet for rate of weight loss could be low in run 15. (Thus large gains in radiation and weight loss were not shown. The 3- to 5foot measure does not represent the actual rate of weight loss.)

${ }^{6}$ Variation within fires on these two runs is greater than variation in between. Radiation not uniform as afterburning occurred extensively in run 21 . 
Table 10.--" " $t$ " test for length of drying time

\begin{tabular}{|c|c|c|c|c|c|c|c|c|c|}
\hline \multirow[b]{2}{*}{$\begin{array}{c}\text { Runs } \\
\text { compared }\end{array}$} & \multirow{2}{*}{\multicolumn{2}{|c|}{$\begin{array}{l}: \text { Dryness } \\
: \text { condition } \\
: \text { amount } \\
\text { : retardant }\end{array}$}} & : & \multicolumn{2}{|c|}{ Rate of spread } & \multicolumn{2}{|c|}{ Radiation } & \multicolumn{2}{|c|}{$\begin{array}{ll}: & \text { Weight loss } \\
: \quad & \quad \text {. }\end{array}$} \\
\hline & & & : & $\begin{array}{l}\text { Average } \\
\text { rate of } \\
\text { spread }\end{array}$ & $\begin{array}{l}\text { : Significance } \\
: \text { of rate of } \\
: \text { spread }\end{array}$ & $\begin{array}{ll}: & \text { Average } \\
: & \text { radiation } \\
\end{array}$ & $\begin{array}{l}\text { Significance } \\
\text { of radiation }\end{array}$ & $\begin{array}{c}\text { Rate of } \\
: \text { weight loss } \\
\end{array}$ & $\begin{array}{l}\text { : Significance } \\
: \text { of rate of } \\
: \text { weight Ioss }\end{array}$ \\
\hline & & & & Ft./min. & Percent & BTU/sq.ft./hr. & Percent & Lbs./min. & Percent \\
\hline 1 & $1 / 3 I$ & & ST & 0.222 & & 6.47 & & 0.16 & \\
\hline 7 & $2 / 31$ & & ST & .349 & 97.5 & 10.29 & 95 & .23 & 95 \\
\hline 3 & $1 / 3 \mathrm{II}$ & & ST & .264 & & 11.42 & & .21 & \\
\hline 10 & $2 / 3$ Il & & ST & .405 & 99.5 & 7.69 & * I 95 & .27 & 95 \\
\hline 11 & $2 / 3 \mathrm{I}$ & & LT & .169 & & 5.10 & & .14 & \\
\hline 17 & F I & & $\mathrm{LT}$ & .205 & ${ }^{2} 80$ & 5.75 & 90 & .14 & ${ }^{2}$ N.S. \\
\hline 12 & $2 / 3 \mathrm{I}$ & & LT & .233 & & 5.62 & & .15 & \\
\hline 18 & F I & & LT & .444 & 99.5 & 9.21 & 90 & .28 & 95 \\
\hline 13 & $2 / 3 \mathrm{II}$ & & LT & .216 & & 6.82 & & .19 & \\
\hline 19 & F II & & LT & .231 & 270 & 6.53 & $* 260$ & .17 & $* 270$ \\
\hline 14 & $2 / 3$ II & & LT & .418 & & 9.31 & & .25 & \\
\hline 20 & F II & & $\mathrm{LT}$ & .515 & 90 & 12.33 & 90 & .32 & 70 \\
\hline 15 & $2 / 3 \amalg$ & 2 & LT & .290 & & 7.28 & & .16 & \\
\hline 21 & $\mathrm{~F} \quad$ III & & & .320 & ${ }^{2} 60$ & 6.35 & $* 270$ & .19 & 280 \\
\hline 16 & $2 / 3$ III & & LT & 1.208 & & 17.21 & & .42 & \\
\hline 22 & F IIl & & LT & 1.711 & 97.5 & 15.33 & *360 & .42 & ${ }^{3}$ N.S. \\
\hline
\end{tabular}

* Significance in the reverse direction.

${ }^{I}$ Same as for 3 on conditions--run 10 had very little afterburning. Flame front had not reached the 5- to 7-foot area during the time the rate of spread showed it to be there, thus causing a low radiation measure.

${ }^{2}$ The effect of dryness with this long-term retardant of $2 \mathrm{~N}$ amount is not significant. The $2 / 3 \mathrm{dry}$ seems to be as effective as the fully dry, as shown in comparisons of runs 11 and 17, 13 and 19 , and 15 and 21 .

${ }^{3}$ These low significant differences are probably due to the Iarge amount of variation within run 16 .

Table 11.--" $t$ " test for type of retardant--long-term or short-term

\begin{tabular}{|c|c|c|c|c|c|c|c|c|c|c|}
\hline \multirow[b]{2}{*}{$\begin{array}{c}\text { Runs } \\
\text { compared }\end{array}$} & \multirow{2}{*}{\multicolumn{2}{|c|}{$\begin{array}{l}\text { Dryness } \\
\text { condition } \\
\text { amount } \\
\text { retardant }\end{array}$}} & : & \multicolumn{2}{|c|}{ Rate of spread } & \multicolumn{3}{|c|}{ Radiation } & \multicolumn{2}{|c|}{ : Weight loss } \\
\hline & & & $\begin{array}{l}: \\
: \\
:\end{array}$ & $\begin{array}{l}\text { Average } \\
\text { rate of } \\
\text { spread }\end{array}$ & $\begin{array}{l}\text { Significance } \\
: \text { of rate of } \\
: \quad \text { spread }\end{array}$ & $\begin{array}{l}\text { Average } \\
: \text { radiation } \\
\end{array}$ & $\begin{array}{l}: \mathrm{S} \\
: \mathrm{c} \\
:\end{array}$ & $\begin{array}{l}\text { ignificance } \\
\text { f radiation }\end{array}$ & $\begin{array}{l}: \text { Rate of } \\
: \text { weight loss } \\
:\end{array}$ & 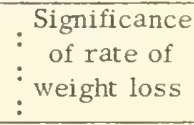 \\
\hline & & & & $\mathrm{Ft} . / \mathrm{min}$. & Percent & BTU/sq.ft./ & & Percent & Lbs./min. & Percent \\
\hline 7 & $2 / 3 \mathrm{I}$ & $2 \mathrm{ST}$ & & 0.349 & & 10.29 & & & 0.23 & \\
\hline 11 & $2 / 3 \mathrm{I}$ & $2 \mathrm{LT}$ & & .169 & 97.5 & 5.10 & & 97.5 & .14 & 97.5 \\
\hline 10 & $2 / 3 \mathrm{II}$ & $2 \mathrm{ST}$ & & .405 & & 7.69 & & & .27 & \\
\hline 13 & $2 / 3$ II & $2 \mathrm{LT}$ & & .216 & 99.5 & 6.82 & & 60 & .19 & 80 \\
\hline
\end{tabular}




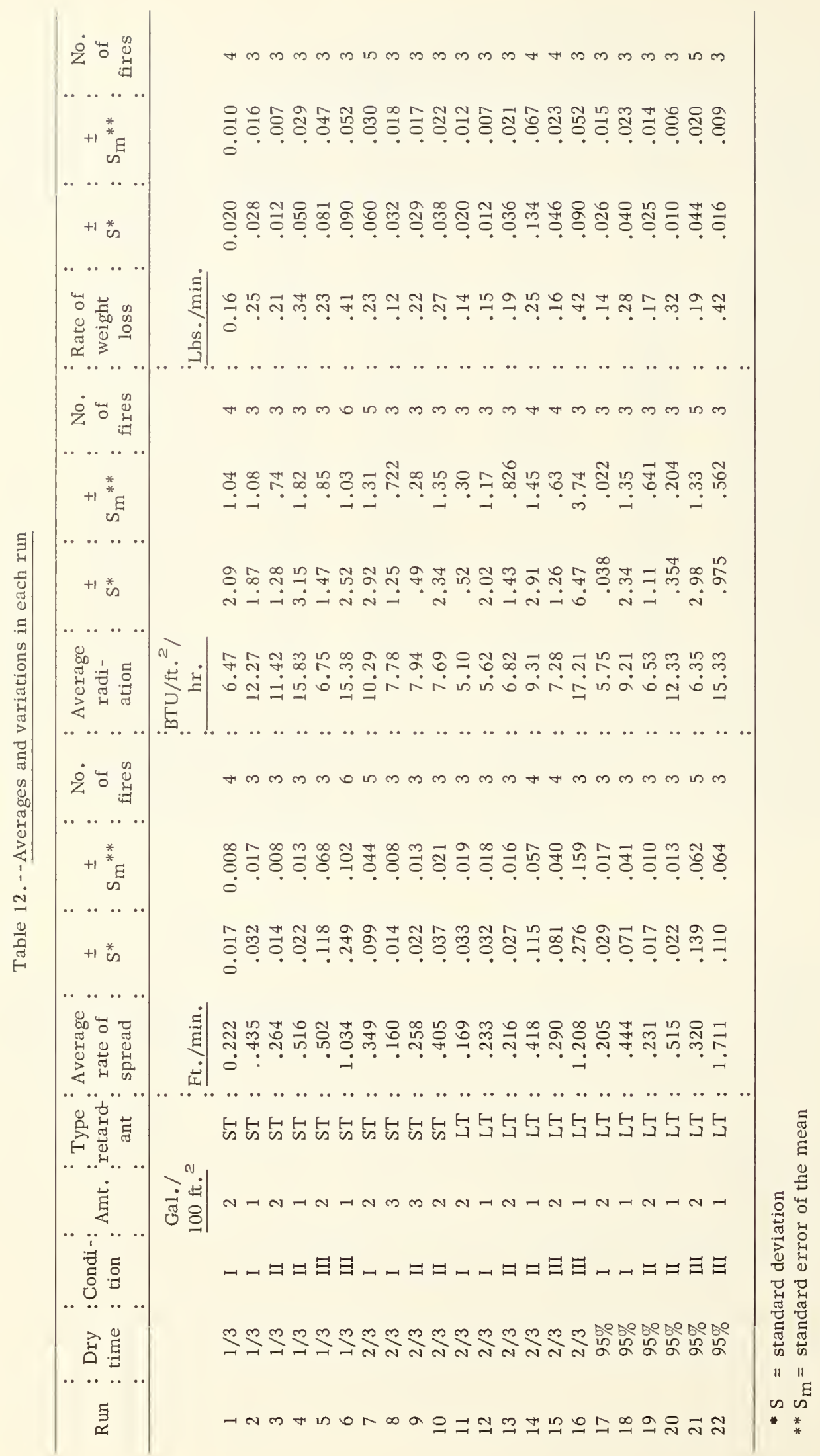


Headquarters for the Intermountain Forest and Range Experiment Station are in Ogden, Utah. Project headquarters are also at:

Boise, Idaho

Bozeman, Montana (in cooperation with Montana State University)

Logan, Utah (in cooperation with Utah State University)

Missoula, Montana (in cooperation with University of Montana)

Moscow, Idaho (in cooperation with the University of Idaho)

Provo, Utah (in cooperation with Brigham Young University) 


\section{FOREST SERVICE CREED}

The Forest Service of the U.S. Department of Agriculture is dedicated to the principle of multiple use management of the Nation's Forest Resources for sustained yields of wood, water. forage, wildlife, and recreation. Through forestry research, cooperation with the States and private owners, and management of the National Forests and National Grasslands, it strives - as directed by Congress - to provide increasingly greater service to a growing Nation. 